\title{
Plastics in the Indian Ocean - sources, fate, distribution and impacts
}

Charitha Pattiaratchi ${ }^{1}$, Mirjam van der Mheen ${ }^{1}$, Cathleen Schlundt ${ }^{2}$, Bhavani E. Narayanaswamy ${ }^{3}$, Appalanaidu Sura ${ }^{4}$, Sara Hajbane ${ }^{1}$, Rachel White ${ }^{5}$, Nimit Kumar ${ }^{6}$, Michelle Fernandes ${ }^{7}$, Sarath Wijeratne $^{1}$

${ }^{1}$ Oceans Graduate School and the UWA Oceans Institute, the University of Western Australia, Perth, 6009, Australia

${ }^{2}$ GEOMAR, Helmholtz Centre for Ocean Research, Kiel, Düsternbrooker Weg 20, 24105 Kiel, Germany

${ }^{3}$ Scottish Association for Marine Science, Oban, Argyll, PA37 1QA, Scotland, UK

${ }^{4}$ National Centre for Coastal Research, Ministry of Earth Sciences, Chennai, 600100, India

$10 \quad{ }^{5}$ School ofBiological Sciences, the University of Western Australia, Perth, 6009, Australia

${ }^{6}$ Ministry of Earth Sciences (MoES), Indian National Centre for Ocean Information Services (INCOIS), Hyderabad-500090, India.

${ }^{7}$ National Centre for Polar and Ocean Research, Ministry of Earth Sciences, Goa, India

Correspondence to: Charitha Pattiaratchi (chari.pattiaratchi@uwa.edu.au)

\section{Abstract.}

Plastic debris are the most common and exponentially increasing human pollutant in the world's oceans. The distribution and impact of plastic in the Pacific and Atlantic Oceans have been the subject of many publications but not so the Indian Ocean

20 (IO). Some of the IO rim countries have the highest population densities in the world and mis-management of plastic waste is of concern in many of these rim states. Some of the highest plastic-polluted rivers end up in the IO with all this suggesting that the IO receives a tremendous amount of plastic debris each year. However, the concentration, distribution and impacts of plastics in the IO are poorly understood as the region is under-sampled compared to other oceans. In this review, we discuss sources and sinks, which are specific for the IO as well as unique atmospheric, oceanographic and topographic features of the IO such as reversing wind directions due to the monsoon, fronts and upwelling regions that control plastic distribution. We identified hotspots of possible plastic accumulation in the IO, which were different in the two hemispheres. In the northern Indian Ocean, the majority of the plastic material will most likely end up being beached due to the absence of a sub-tropical gyre, whereas in the southern Indian Ocean, the garbage patch is not well defined and there may be leakage of plastics into the southern Atlantic Ocean. Hotspots of predicted plastic accumulations are identified here as well as the vast knowledge gaps 30 about the plastic issue of the IO and point to the most striking future investigation topics. 


\section{Introduction}

Historically, the motivation for the development of synthetic materials like plastics was for the conservation of elephants that inhabit countries along the Indian Ocean (IO) rim in southern Asia and Africa. In the late 19th century, the game of billiards

35 was extremely popular where the billiard balls were made from ivory coming from elephant tusks. This was the start of elephants becoming threatened with extinction (Freinkel, 2011). A New York billiards manufacturer devised a contest in 1850 's, rewarding anyone who came up with a suitable alternative material for the billiard balls (Seymour and Kauffman, 1993). John Wesley Hyatt produced the first semi-synthetic material, which he called celluloid; however, it was highly flammable and volatile and produced a minor explosion when the balls hit each other. Hyatt never received his reward, but he

40 found several uses where celluloid could replace natural materials. Celluloid was advertised as a saviour of the environment, because it would no longer be necessary to ransack the environment for scarce natural resources (Meikle, 1997). In the early 1900s, Leo Baekeland produced the first fully synthetic material, which he dubbed Bakelite (Crespy et al., 2007). Unlike celluloid, Bakelite could be moulded into any shape and thus was extremely diverse in its applications. Its invention triggered the development of many more synthetic polymers around the world. During World War II, when import and export of natural 45 resources were limited, the military used synthetic materials for anything from tyres to parachutes (Beckman, 2018). As a result, plastic production became a mass-produced product and nearly quadrupled during the war (Freinkel, 2011).

After World War II, plastic producers turned their attention to the consumer market and the production of plastic materials has increased exponentially since the 1950s (PlasticsEurope, 2019). Since a large percentage of all plastics are single use, 50 "throwaway" packaging items, plastic waste has increased at a similar rate. Since the 1950s, the global human population has generated an estimated 8300 million tonnes of plastic, of which over 75\% (6300 million tonnes) has been discarded as waste (Geyer et al., 2017). Almost $80 \%$ of this plastic waste either ends up in landfill or in the environment. As a result, several million tonnes of plastic waste are estimated to enter the global oceans every year from coastlines (Jambeck et al., 2015), from inland sources transported by rivers (Lebreton et al., 2017; Schmidt et al., 2017; 2018); or directly from ocean-based sources such as the global fishing industry (Richardson et al., 2019), offshore platforms and commercial and recreational shipping.

Plastic materials are durable and very slow to degrade and can persist in the marine environment for decades to centuries (Barnes et al., 2009). Around 35\% of all plastic materials produced globally have densities higher than that of seawater, and thus can sink to the seafloor. The remaining $65 \%$ of plastics float in the ocean and can travel enormous distances in the ocean.

60 Photodegradation and other weathering processes at the sea surface lead to fragmentation, increasing micro- and nanoplastic abundance (Andrady, 2011). Plastics also accumulate biofouling while in the ocean, which can change the overall density and lead to plastics moving vertically in the water column. As a result, plastics are ubiquitous throughout the marine environment and have been found on remote islands (Duhec et al., 2015; Lavers and Bond, 2017), in polar ice (Obbard et al., 2014; 
Bergmann et al., 2017; Peeken et al., 2018), and in the deep-seas (Van Cauwenberghe et al., 2013; Jamieson et al., 2019;

65 Courtene-Jones et al., 2020).

Plastic pollution has several known harmful effects on marine species and ecosystems, including ingestion, entanglement, and the transport of potentially invasive species into foreign remote habitats (Gregory, 2009; Law, 2017). Plastics can also absorb and transfer toxicants (Rochman et al., 2012), potentially leading to the accumulation of toxins across the food web (Engler,

70 2012). Marine plastic debris also causes significant economic damage to industries and communities, with estimated costs ranging between USD 8 billion (Raynaud, 2014) to USD 2500 billion (Beaumont et al., 2019). Economic costs can be caused by damage to ships and fishing equipment when they collide with big marine plastic fragments; by soiled landscapes that impair the tourism industry when it relies on clean beaches and coastal waters; and by a decline in the amount and quality of captured fish and seafood.

75

However, the overall impact of plastic pollution in the ocean is still poorly understood (Law, 2017). There are challenges in investigating ecological impacts and the fate of plastics in the ocean. Estimates of the amount of plastic floating on the global ocean surface are approximately $1 \%$ or less of the estimated amount of plastic that enters the ocean per year (van Sebille et al., 2015). This discrepancy in the global ocean plastic budget highlights a fundamental gap in the understanding of the fate of 80 ocean plastic and suggests that there are unknown sinks of marine plastic debris. Possible sinks include biological sinks, i.e. organisms ingesting plastics (Davison and Asch, 2011); sea ice cover temporarily accumulating plastics (Obbard et al., 2014; Peeken et al., 2018); fragmentation and biofouling of plastics leading to settling (Koelmans et al., 2017); and plastics making landfall ("beaching”) and accumulating on the world's coastlines (Lebreton et al., 2019; van der Mheen et al., 2020c).

85 Plastic debris in the IO has been under-sampled and under-studied compared to other oceans, whilst the fate of plastics has not been investigated in any detail. However, a large percentage of all global ocean plastic is estimated to enter the IO; up to $15 \%$ of all coastal plastic (Jambeck et al., 2015) and 20\% of all riverine plastic (Lebreton et al., 2017; Schmidt et al., 2017; 2018). Half of the top ten countries contributing most to ocean plastic pollution are located along the Indian Ocean rim (Indonesia, Thailand, Malaysia, India and Bangladesh), and two of the largest and most polluting rivers (Ganges and Indus) empty into

90 the Indian Ocean. In addition, it has been estimated that the Indian Ocean contains the second largest plastic loading in the ocean after the North Pacific Ocean (Eriksen et al., 2014), although there are insufficient measurements of plastics available in the Indian Ocean to confirm this. In this synthesis paper, we compile existing knowledge about the sources (section 2), observations (section 3), transport (section 4), fate (section 5), impact (section 6), prevention and mitigation (section 6) of plastic debris in the IO as well as highlight some of the emerging policies and initiatives, knowledge gaps and recommend 95 future research strategies (section 7). 


\section{Sources}

Plastic waste enters the IO from coastal sources transported by wind and tides, from sources far into the hinterland transported by rivers, and directly from ocean-based sources. The Indian Ocean is surrounded by 34 countries with population densities of around 100 people per $\mathrm{km}^{2}$ on average, with Australia the least populated country ( 3 people per $\left.\mathrm{km}^{2}\right)$ and India the most populated country (400 people per $\mathrm{km}^{2}$ ). Hoornweg and Bhada-Tata (2012) estimated that the total amount of plastic waste produced by all Indian Ocean rim countries in 2010 was around 41 million tonnes. In comparison, the total amount of plastic waste produced in 2010 by the USA and China alone, is estimated to be 38 and 59 million tonnes, respectively. Despite the relatively low plastic waste production around the IO rim, a large percentage ends up in the environment because of poor waste management in most Asian and African countries. Hoornweg and Bhada-Tata (2012) estimated that around 73\% of plastic waste is inadequately managed along the IO rim and is released into the environment.

\subsection{Land-based sources}

Jambeck et al. (2015) estimated the global amount of plastic waste that entered the ocean in 2010 from coastal populations living within $50 \mathrm{~km}$ of the coastline. Based on a fixed percentage of mismanaged plastic waste entering the oceans $(15 \%$ and $40 \%$ for the low- and high-range estimates respectively), they estimated that between 4.8 and 12.7 million tonnes of plastic entered the global oceans. Around $15 \%$ of global ocean plastic entered the IO (Figure 1a). However, there was an error in the Jambeck et al. (2015) estimate of the amount of mismanaged plastic waste that enters the ocean in Sri Lanka with this error originating from the World Bank Data (Hoornweg and Bhada-Tata, 2012) which overestimated the plastic waste entering from Sri Lanka by a factor 10. We have corrected this, as shown in Figure 1a, as well as in the estimate that approximately $15 \%$ of global ocean plastic enters the IO.

Lebreton et al. (2017) and Schmidt et al. (2017) both estimated the amount of plastic waste entering the oceans through rivers. Similar to Jambeck et al. (2015), their estimates are based on a percentage of mismanaged plastic waste but also include the influence of river catchment geography and river discharge. In addition, these estimates were calibrated based on available measurements of river plastic debris around the world, ranging between sizes of $0.3 \mathrm{~mm}$ to $0.5 \mathrm{~m}$. Lebreton et al. (2017) estimated that between 1.15 and 2.41 million tonnes of plastic waste enter the global ocean per year, up to $20 \%$ of which enters the IO (Figure 1b). Schmidt et al. (2017) estimated that between 0.47 and 2.75 million tonnes of plastic waste enter the global ocean per year, of which around $15 \%$ enters the IO. The estimates of the amount of plastic waste entering the oceans through rivers by Lebreton et al. (2017) and Schmidt et al. (2017) agree relatively well with each other. In contrast, the estimates by Jambeck et al. (2015) of the amount of plastic waste entering the oceans through coasts are an order of magnitude higher.

The largest coastal and riverine plastic sources in the IO are in the northern hemisphere around the Bay of Bengal and on the eastern side of the Arabian Sea (Figure 1). The input of plastic waste from rivers mainly depends on the river discharge, which 
varies seasonally. The highest river discharges occur during the wet season, which occurs during the boreal summer in the northern IO. Lebreton et al. (2017) estimated that plastic waste input from rivers in the IO peaks in August (Figure 1c). In the southern hemisphere, the largest coastal and riverine sources of IO plastic waste are from Indonesia and eastern Africa (Figure 1b).

\subsection{Ocean-based sources}

Plastic waste can also enter the ocean directly from ocean-based sources such as the fishing industry, commercial and recreational shipping, and offshore platforms. Although the International Convention prohibited the dumping of waste from vessels in 1988 for the Prevention of Pollution from Ships (MARPOL), accidental losses and illegal dumping still contribute to plastic debris. Abandoned, Lost, or Discarded Fishing Gear (ALDFG) by the fishing industry can produce large quantities of plastic debris, i.e. monofilament lines and nets primarily made from synthetic materials (Sheavly and Register, 2007; Bond et al., 2012). Since 2000, around 13\% of the global marine capture of fishes originated from the IO region (Pauly and Zeller, 2016). It is therefore likely that ALDFG is a significant source of plastic debris in the IO. Estimates of plastic waste entering

140 the ocean from fishing vessels (e.g. ghost nets) or offshore platforms do not currently exist.

Finally, plastic waste originating from south-east Asia can also be transported to the IO by the Indonesian Throughflow (section 4.1). However, these sources are currently undocumented and need to be further investigated.

\section{Observations}

145 Plastics have been sampled in the IO in coastal waters, the open ocean, sediment, and organisms since the 1980s (Table 1) with most sampling studies being conducted on beaches. However, measurements are relatively scarce, and plastics have been regularly under-sampled in the IO (Fig. 2a) compared to the Atlantic and Pacific oceans. Samples of plastic debris consists of different plastic polymers and are generally classified into different type, and size categories. Commonly used type categories are plastic fibres, fragments, films, and pellets. Size categories of marine plastic debris can range from $1 \mu \mathrm{m}$ to $1 \mathrm{~m}$ or larger 150 and are often divided into nanoplastics, microplastics, mesoplastics, macroplastics, and sometimes megaplastics (van Sebille et al., 2020). Size categories as defined by GESAMP (2018; Frias and Nash, 2019) are: $<0.1 \mathrm{~mm}$ (nanoplastics); 0.33-1.00mm (small microplastics); 1.01-4.75mm (large microplastics); 4.76-200 mm (mesoplastic); and, > $0.200 \mathrm{~mm}$ (macroplastics). However, these categories can vary widely between authors (Frias and Nash, 2019) and it is beyond the scope of this review to define them all.

The most abundant polymers identified on beaches in the IO are high- and low- density polyethylene (HDPE and LDPE, respectively); high- and low density polypropylene (HDPP and LDPP, respectively); polystyrene (PS); polypropylene (PP); 
and polyethylene terephthalate (PET). In water and in sediment, the most abundant polymers are HDPE, LDPE, PE, PP, and PS (Sruthy and Ramasamy, 2016; Koongolla et al., 2018; Robin et al., 2020). However, all types of plastics were found in

160 water and sediment samples (fibres, fragments, films, and pellets). The few studies undertaken on benthic invertebrates (Taylor et al., 2016; Courtene-Jones et al., 2017; Thushari et al., 2017; Naidu et al., 2018; Jamieson et al., 2019) and commercial fishes (Baalkhuyur et al., 2019; Karthik et al. 2018) identified HDPE, LDPE, PE, PES, PP, PS, and PET polymers as well as natural fibres.

165 Global open ocean plastic samples were standardised by van Sebille et al. (2020) and the plastic concentrations from these samples in the IO can be quantitatively compared (Figure 2a). In contrast, the methods and units used in the sampling of plastics on beaches vary widely and offer only a qualitative confirmation that plastics have been found on beaches throughout the IO (Figure 2b). In general, the collection and preservation, optimised protocols for microplastic extraction (water, sediments, fauna), and identification methods (e.g. visual or analytical) vary between studies (as illustrated in Table 1) and are still under development. This therefore highlights the need for a standardised global protocol for the study of plastic debris and should be a major priority in ocean plastic research going forward.

\section{Transport}

Approximately $35 \%$ of all produced plastic materials have densities higher than that of seawater (PlasticsEurope, 2019) and, therefore will sink to the seafloor after entering the ocean. To the best of our knowledge, there have been no studies in the IO

175 regarding sinking plastics and the transport of plastics through the water column and along the seafloor. Most plastic materials float in the ocean and are transported by ocean surface dynamics (currents, wind, and waves). However, buoyant plastic debris can be vertically distributed in the upper few metres of the water column because of wind- and wave- induced mixing (Kukulka et al., 2012; Kukulka and Brunner, 2015; Brunner et al., 2015). Depending on the sea state and the characteristics of the plastic debris, sampling studies in the North Atlantic Ocean found plastic debris mixed up to $5 \mathrm{~m}$ depth in the water column (Reisser

180 et al., 2015; Kooi et al., 2016). In addition, the density of plastic debris can change under the influence of biofouling and degradation. As a result, initially buoyant plastics may then sink. These plastics can also become de-fouled in the water column because of foraging and decreasing light intensities, which can lead to plastics oscillating in the water column (Andrady, 2011; Kooi et al., 2017). Fallouts of plastic into the water column and the deep sea have recently been detected below the subtropical garbage patch in the North Pacific Ocean (Egger et al., 2020). In the IO, mixing of buoyant plastics in the water column and sinking of initially buoyant plastics have not yet been studied. In this section, we therefore focus only on the transport of buoyant plastics by ocean surface dynamics in the IO. 
Buoyant plastics drifting at the ocean surface are transported by different forcing mechanisms. Recent reviews by Zhang et al. (2017) and van Sebille et al. (2020) discuss these processes and their influence on the transport of plastics in detail. Ocean surface currents play a dominant role in the transport of buoyant objects but wind (Breivik and Allen, 2008) and surface gravity waves (Röhrs, et al., 2012) can have a significant influence on an object's behaviour. Ocean surface currents are forced by many different mechanisms such as wind, waves, tides, and density gradients (Talley et al., 2011; van Sebille et al., 2020). In combination with the Coriolis force, these forcing mechanisms result in Ekman currents, geostrophic currents, and Stokes drift that transport plastics. In addition to the indirect influence of the wind (i.e. forcing ocean surface currents and generating waves), the wind can also have a direct influence on the transport of buoyant objects through "windage", where the wind acts on an object's surface area exposed to air (Richardson, 1997). Currents, wind, and waves have large temporal and spatial variations, both horizontally and vertically. Ocean surface currents typically have a pronounced vertical profile, with current speeds decaying rapidly with depth (Laxague et al., 2017) and which can have a significant influence on the transport of buoyant objects (van der Mheen et al, 2020b). The different forcing mechanisms that transport buoyant plastics are rarely independent and interact with each other in complex ways. In addition, depending on their specific characteristics (e.g. size, shape, density), buoyant objects can react differently to the same forcing conditions (Maximenko et al., 2012).

\subsection{Plastic transport and accumulation along ocean fronts}

Plastics entering the ocean from land-based sources are subject to many physical processes on the continental shelf before they are transported into the deeper ocean or beach on coastlines. Several studies investigating plastic debris in the IO have mainly focussed on the biology and biogeochemistry (Roy et al., 2015; Sarma et al., 2015; Sarkar et al., 2018) and only a few studies have addressed the transport of plastics between inshore and offshore regions. Physical processes that lead to convergent flows are one of the most important features for the transport of buoyant plastics. Convergent flows promote downwelling causing an accumulation along the convergent flow boundary of buoyant plastic debris.

210 Convergent flows occur along ocean fronts, defined as the boundary between two distinct water masses or a region where the rate of change of selected physical properties is much greater than the surrounding areas (Bowman and Esaias, 1977; Belkin and Cornillon, 2007; D'Asaro et al., 2018). Fronts occur from hundreds of metres to many thousand kilometres and some are short-lived, but most are quasi-stationary and emerge at the same location on seasonal time scales (Belkin and Cornillon, 2007). Ocean fronts are considered hotspots of marine life (Belkin et al., 2009) because flow convergence at fronts channelling

215 nutrients towards the fronts and stimulating increased production at different trophic levels (Owen, 1981; Baltar et al., 2016; Sarma et al., 2015; Woodson and Litvinb, 2015; Sarkar et al., 2018). Aggregations of plankton, larvae, and eggs are often found on the surface. Here, as the water sinks at the front due to convergent flow buoyant material will remain at the surface. Predators such as fish and higher order biota are found above and beneath the front. Due to the accumulation of buoyant debris, including plastics, along fronts, the risk of marine organisms interacting with plastics is high. 
There are many types of fronts that are formed through different physical processes. They include: river plumes (Luketina and Imberger 1988; O’Donnell et al., 1998; Karati et al., 2018; Cole et al., 2020); shelf-sea tidal fronts (Simpson and Hunter, 1974; Nahas et al., 2005; Sharples and Simpson, 2020); shelf break fronts (Sharples and Simpson, 2020); upwelling fronts (Brink, 1987); and, fronts formed through interaction between flow and topography (Haury and Hamner, 1986; Pattiaratchi et al.,

225 1987). Fronts appear as a visible band along the sea surface with differences in temperature and salinity (and as a result, density) on either side of the front. All these different types of fronts occur in the IO and are extremely important for the accumulation of plastics.

Buoyant plastics entering the IO from land-based sources such as rivers may accumulate at many different frontal systems before they are transported offshore. During the Southwest monsoon season (section 4.2), coastal fronts are generally formed by the interaction of two different water masses moving in opposite directions, where the low saline runoff waters from rivers are trapped as a salinity front by the high saline upwelling waters. Examples of such fronts are along the southern coast of Sri Lanka (de Vos et al., 2013).As a result, buoyant plastic debris is trapped in the frontal zone along these water masses (Naidu et al., 2021 in subm.) referring to locations of future investigations. Naidu et al. (2021 in subm.) also found that the abundance

235 of plastics, mainly fibres and fragments, were an order of magnitude higher in the frontal zone compared to outside of it off the west coast of India. Similarly, Hajbane et al. (2021) found that close to an offshore reef located in the eastern IO, concentrations of plastics along a coastal front were up to two orders of magnitude higher than in surrounding waters. Frontal systems can also be eroded under storm conditions (e.g. Chen et al., 2020) and as a result, plastics accumulated along coastal fronts may beach on coastlines.

\subsection{Indian Ocean surface dynamics and plastic transport pathways}

Compared to other ocean basins, the IO has several unique topographic, atmospheric, and oceanic features that influence the transport of buoyant plastics. The IO is a unique ocean because three continents and spans temperate to sub-polar regions surround it. To the north the IO is bounded by the Indian subcontinent, to the west by Africa and the Middle East, to the east by Indonesia and Australia, and in the south by the Southern Ocean. There are two distinctive tropical basins in the northern

245 IO: the Arabian Sea in the west and the Bay of Bengal in the east. The IO is connected to the Pacific Ocean through the Indonesian Archipelago that allows tropical water inflow from the Pacific Ocean. In the southern IO, the eastern boundary formed by the African continent does not extend beyond $35^{\circ} \mathrm{S}$, which allows for a connection between the southern IO and the South Atlantic Ocean (Gordon, 2003; Lutjeharms, 2006) and facilitates plastic transport between these oceans leading to an debris exchange between the garbage patches (van der Mheen et al., 2019; section 4.3). The presence of the land mass in the northern IO results in there being no subtropical gyre. Instead, temperature differences between the northern land mass and 

determine the transport of buoyant plastics in the IO (van der Mheen et al., 2020a) and are described in more detail here.

\subsubsection{Northern Indian Ocean surface dynamics and plastic transport pathways}

The atmospheric dynamics in the IO are characterised by bi-annually reversing monsoon winds due to seasonal differential heating and cooling of the continental land mass and the ocean (Schott et al., 2009). The Southwest (SW) monsoon generally operates between June and October and the Northeast (NE) monsoon operates between December through April (Tomczak and Godfrey, 2003). The transition periods between the monsoon seasons are the First Inter-Monsoon (May) and Second InterMonsoon (November). The influence of the monsoon system is not limited to the northern IO. Unlike in the other oceans, there are no steady equatorial easterly trade winds in the northern IO. Instead, they only have an easterly component during the NE monsoon season and are westerly during the rest of the year. In addition, the SW monsoon season starts with strengthened south-easterly trade winds in the southern IO (Findlater, 1969; Joseph and Sijikumar, 2004).

These strong, seasonally reversing winds drive the ocean surface currents and circulation patterns in the northern IO (Stramma et al., 1996; Shankar and Shetye, 1997; Schott and McCreary, 2001; Shenoi et al., 2004). During the SW monsoon season, the

265 flow in the northern IO is predominantly towards the east (Figure 4a), from the Arabian Sea into the Bay of Bengal, and the westward flowing North Equatorial Current (NEC) does not exist (Schott et al., 2009). Along the coastlines of India and Sri Lanka in the Arabian Sea, the West Indian Coastal Current (WICC) flows southwards along the western Indian coastline and joins the eastward flowing Southwest Monsoon Current (SMC). The SMC flows from the Arabian Sea past Sri Lanka and into the Bay of Bengal (de Vos et al., 2014). After passing the coast of Sri Lanka, the ocean surface currents form an anti-clockwise eddy called the Sri Lanka Dome (SLD; Su et al., 2021). The western arm of this eddy drives a southward current along the eastern coast of Sri Lanka; the remainder flows northwards along the eastern Indian coastline as the East Indian Coastal Current (EICC). At the eastern boundary, the South Java Current (SJC) is variable but flows predominantly to the north west along the Java coast (Sprintall et al., 2009), in the same direction as the Indonesian Throughflow (ITF), which is strongest during the SW monsoon (Sprintall et al., 2009). At the western boundary of the northern IO, the Somali Current (SC) flows northeastwards during this season.

During the NE monsoon season, the ocean surface currents reverse direction and the flow in the northern IO is predominantly towards the west (Figure 4b), from the Bay of Bengal towards the Arabian Sea (Schott et al., 2009). Both the WICC and the EICC along the Indian coasts reverse direction and the SMC reverses and becomes the Northeast Monsoon Current (NMC), which is weaker than the SMC (de Vos et al., 2014). Together with the East African Coastal Current (EACC), the SC supplies the eastwards South Equatorial Counter Current (SECC). The SECC feeds into the SJC, which flows south-eastwards along the coasts of Sumatra and Java during this season. Another unique feature in the equatorial IO is the strong eastward flowing 
Wyrtki jets (Wyrtki, 1973) that develop along the equator during the First and Second Inter-Monsoon. These jets are at their strongest during the Second Inter-Monsoon (Qui and Yu, 2009).

The main features to note from the description of the ocean surface currents in the northern IO is the reversal of major currents with the monsoon season. Particle tracking simulations illustrate that these reversing currents transport buoyant objects between the eastern and western section of the northern IO with Sri Lanka and the Maldives in the central section (Figure 5; van der Mheen et al, 2020a). In addition, the net surface transport in the northern IO is eastwards (Schott et al., 2009), because of the strong eastwards SMC, as well as the eastward flowing Wyrtki jets between monsoon seasons. This net eastward transport, combined with eddies developing year-round in the Bay of Bengal and potentially trapping plastics, result in plastics being present in the Bay of Bengal throughout the year. In contrast, the Arabian Sea, is mostly depleted of plastics during the SW monsoon season (Figure 5). However, if sources of plastics increase it is likely that concentrations will also increase. As plastics are transported back and forth between the Arabian Sea and the Bay of Bengal, they frequently come close to

295 coastlines. Because of this, it is likely that a large amount of plastic beaches and accumulates on northern IO coastlines (van der Mheen et al., 2020a; section 5.2).

To illustrate the influence of these unique features in the northern IO on the transport of buoyant objects, a particle tracking simulation was undertaken using surface advection fields from the global ocean circulation model HYCOM and the particle tracking model ICHYTOPOP. Passive particles $(100,000)$ were released at a location to the south of Sri Lanka (Figure 4) on 1 Sep 2019 (end of the south-west monsoon) and tracked over a period of 12 months. This location was selected as a central location where current reversals driven by the monsoon, but it does not reflect a source of plastics (see section 4). During the first two months of the simulation (1 November), most of the particles were advected in an easterly direction to the Andaman sea by the eastward currents generated by the south-west monsoon (Figure 4a). Two months later (1 January), the particles were advected to the west under the influence of the westward currents due to the north-east monsoon (Figure 4b). Particles were present along the coasts of India, Sri Lanka, The Maldives and in the northern Bay of Bengal. When the inter-monsoon period started (1 March), particles were transported to the north in both the Bay of Bengal and the Arabian Sea by the Indian coastal currents and almost to Somalia (Figure 4c). On 1 May, particles beached in Somalia and were present in $>80 \%$ of the surface area of the Arabian Sea and Bay of Bengal (Figure 4d). Particles also beached in Bangladesh and Indonesia (Sumatra)

310 and crossed the equator to the southern hemisphere. With the onset of the south-west monsoon, particles were advected to the east, making landfall along the west coast of India, Myanmar, and Indonesia (Figure 4e). At the end of the 12-month simulation, particles beached in multiple IO rim countries: Tanzania, Kenya, Somalia, the Maldives, Sri Lanka, India (both east and west coasts), Bangladesh, Myanmar, and Indonesia (Figure 4e). This example simulation highlights the influence of the reversing monsoon currents on the transport of buoyant material that can extend from west to east across the northern

315 Indian Ocean over a 12-month period. 


\subsubsection{Southern Indian Ocean surface dynamics and plastic transport pathways}

In the southern IO, similar to other ocean basins, there is a wind-driven subtropical gyre (Figure 4) which in this instance has several unique features. The gyre is bounded in the north by the South Equatorial Current (SEC), which flows westwards and is relatively steady all year round. At the western boundary of the subtropical gyre, the Agulhas Current (AC) flows poleward

320 along the southern African coastline (Beal et al., 2011). The Agulhas Retroflection (AR) and Agulhas Leakage (AL) provide a connection between the southern IO and South Atlantic Ocean (Gordon, 2003; Lutjeharms, 2006). At the eastern boundary, the Leeuwin Current (LC) flows poleward along the western Australian coastline. This is opposite to the equatorward flow expected for a wind-driven subtropical gyre (Pattiaratchi and Woo, 2009). Along the southern Australian coastline, the Flinders Current (FC; Middleton and Cirano, 2002) flows westward from the Pacific Ocean into the southern IO. In the south, the gyre is bounded by the Antarctic Circumpolar Current (ACC). The South Indian Counter Current (SICC) flows eastward through the centre of the subtropical gyre (Lambert et al., 2016), which is opposite to the direction expected from Sverdrup theory (Palastanga et al., 2007; Wijeratne et al., 2018). Similar subtropical counter-currents exist in the other oceans but the SICC is unique because it flows across the full width of the basin and splits into three separate branches as it flows between the southern tip of Madagascar and the western coast of Australia (Menezes, 2014).

Most plastic waste enters the southern IO from the Indonesian Archipelago (Jambeck et al., 2015; Lebreton et al., 2017; Schmidt et al., 2017; 2018; section 2). These plastics are transported westwards across the IO basin by the SEC and into the subtropical southern IO (van der Mheen et al., 2020c). In the subtropics, converging wind-driven Ekman currents lead to downwelling and associated accumulation of buoyant plastics in a subtropical garbage patch. However, because of the unique features of the southern IO subtropical gyre, the dynamics of the garbage patch in the IO are distinctive as well (van der Mheen et al., 2019; section 5.1). As a result of the connection between the southern IO and the South Atlantic Ocean provided by the $\mathrm{AR}$ and AL, plastics can also be transported from the IO into the Atlantic Ocean (van der Mheen et al., 2019; Dobler et al., 2019; section 4.2).

\subsubsection{Transport of plastics between the northern and southern Indian Ocean}

340 Strong ocean surface currents can act as transport barriers for buoyant objects, preventing buoyant objects from crossing these currents (Bower, 1991; Brambilla and Talley, 2006). Due to strong equatorial currents, ocean surface drifters do not tend to cross the equator (Maximenko et al., 2012). It has therefore been suggested that buoyant plastics generally remain in the hemisphere where they originally entered the ocean (Lebreton et al., 2012). However, as previously mentioned, the easterly trade winds are not steady in the IO and as a result, the NEC and SECC are not steady either. The surface of the IO also appears more connected between hemispheres than the other oceans (Froyland et al., 2014). van der Mheen et al. (2020a) therefore suggested that plastics may not remain in their original hemisphere in the IO. Particle tracking simulation results by van der 

by the SJC along the Sumatran coastline. This mainly occurred during the Second Inter-Monsoon in their simulations.

350 van der Mheen et al. (2020c) confirmed that ocean surface drifters mainly cross from the northern IO into the southern IO on the eastern side of the IO basin, along the Sumatran coastline. Drifters mainly crossed during the Second Inter-Monsoon and the NE monsoon season. van der Mheen et al. (2020c) also showed that ocean surface drifters crossing from the southern IO into the northern IO do so along the western side of the basin, predominantly during the SW monsoon season. Drifters cross the equator along the Somalian coast, likely as they are transported by the SC, which is directed north-eastwards during the

355 SW monsoon.

Based on these results, it seems possible for buoyant plastics to cross the equator in the IO. It is however unclear how frequently this occurs.

\subsection{Plastic transport between the Indian, Atlantic, and Pacific oceans}

360 To the best of our knowledge, no studies have currently focussed on the transport of plastics from the Pacific Ocean into the IO through the ITF.

Plastics may also be transported from the IO into the Atlantic and Pacific oceans. Based on ocean surface drifter datasets, van der Mheen et al. (2019) showed that buoyant objects that are transported not only by ocean surface currents, but also by Stokes

365 drift due to waves, and by wind, can move from the southern IO subtropical garbage patch (section 5.1) into the South Atlantic Ocean. Using Lagrangian particle tracking simulations, Dobler et al. (2019) confirmed that plastics that are transported by Stokes drift as well as ocean surface currents move from the southern IO past the South African coastline into to the South Atlantic Ocean. Trajectories of undrogued ocean surface drifters (i.e. transported by ocean surface dynamics, including ocean surface currents, wind, and wave effects) also indicate that transport between these two areas of the ocean is possible (van der 370 Mheen et al. 2020a).

Based on Lagrangian particle tracking simulations, Maes et al. (2018) suggested that there is a "super convergence pathway" connecting the southern IO to the South Pacific Ocean. Their results showed particles being transported eastwards, passing close by the southern Australian coastline from the southern IO into the Pacific Ocean. However, trajectories of ocean surface drifters do not confirm the existence of this super convergence pathway. van der Mheen et al. (2020c) suggested that this may be due either to the lack of observed drifter locations along the southern Australian coast, or due to an under-representation of the westwards flowing Flinders Current (Middleton and Cirano, 2002; Wijeratne et al., 2018, section 4.2) in the ocean circulation model used to force particle tracking simulations by Maes et al. (2018). The existence of a super convergence 
pathway between the southern IO and the South Pacific Ocean along the southern Australian coast therefore still needs further investigation.

\section{Fate}

Buoyant plastic debris tends to accumulate in subtropical garbage patches in the world's ocean (e.g. Moore et al., 2001; Lebreton et al., 2012; Maximenko et al., 2012; van Sebille et al., 2012; Eriksen et al., 2013; van Sebille et al., 2015). However, the large discrepancy between the estimated amount of plastic waste entering the ocean and the amount of plastic floating in the garbage patches highlights a fundamental gap in the understanding of the fate of plastic debris and it is likely that there are large and unknown sinks (e.g. van Sebille et al., 2015). Several theories propose what these additional sinks may be including: (1) biological sinks (i.e. ingestion of plastics by marine organisms; e.g. Davison and Asch, 2011); (2) polar ice sheets acting as temporary sinks (Obbard et al., 2014; Peeken et al., 2018), which is not relevant to the IO; (3) coastlines acting as sinks (Lebreton et al., 2019; van der Mheen et al., 2020a); and (4) sinking of plastics due to density changes by fragmentation and biofouling (Koelmans et al., 2017).

Ingestion of plastics can occur at the ocean surface, in the water column, and on the seafloor. Estimates of plastic ingestion by vertebrates (van Franeker, 2011), (Davison and Ash, 2011), indicate that the global ingestion of plastics could be on the same order of magnitude as the amount of plastics accumulating in subtropical garbage patches (van Sebille et al., 2015). However, to the best of our knowledge, no estimates of the amount of ingested plastic by organisms in the IO currently exists.

Sinking and settling of plastics on the seafloor due to fragmentation and biofouling may be a major sink of plastic debris in the ocean (Koelmans et al., 2017). However, these estimates were based on mass balance models and no evidence of the size of this sink currently exists. The understanding of the exact processes of biofouling, fragmentation, and sinking as well as the

400 timescales on which these occur is limited. As far as we are aware, no studies have focussed on this specific to the IO. However, productivity derived from satellite images revealed strong variability in biological production in the IO, and the IO is one of the most productive regions in the global oceans mainly due to intense upwelling during the southwest monsoon (Qasim, 1977). This high surface productivity results in a high export flux of organic particles from the euphotic zone to the deep sea (Ittekkot et al., 1996; Guptha et al., 1997). Organic particles attached to microplastics in combination may increase their density 405 and thus can accelerate the transport of both to the seafloor. As a result, sinking of plastics may be very relevant in the IO.

Woodall et al. (2014) estimated that 4 billion fibres per $\mathrm{km}^{2}$ were present in the IO region (seamount sediments; 500-1000m depth), and as a result suggested that the deep sea is a major sink for microplastic debris, which should also be investigated in the future. 
Due to a lack of information on ingestion and sinking of plastics specific to the IO, we only consider the southern IO subtropical garbage patch and the accumulation of plastics on coastlines as in more detail.

\subsection{Subtropical garbage patch}

In the subtropical oceans, between 20 to $40{ }^{\circ} \mathrm{N}$ and ${ }^{\circ} \mathrm{S}$, wind-driven Ekman transport leads to convergence and associated

415 downwelling. Because buoyant plastics remain at the ocean surface, they accumulate in so-called garbage patches in these regions. In the IO, subtropical convergence, downwelling, and associated accumulation of plastics only occurs in the southern hemisphere, because the subtropics in the northern IO is blocked by landmass (section 4.2). van der Mheen et al. (2019) showed that the southern IO subtropical garbage patch is unique and behaves very differently to the garbage patches in the Atlantic and Pacific oceans.

Using numerical simulations based on global ocean surface drifter datasets, van der Mheen et al. (2019) showed that the influence of Stokes drift and wind has a significant impact on the behaviour of the southern IO subtropical garbage patch. Under influence of Stokes drift and wind, the subtropical garbage patch centres towards the west of the IO basin, and simulated concentrations are at least a factor of two smaller than in the garbage patches in the other oceans. In addition, the IO garbage

425 patch empties into the South Atlantic Ocean over time (see also section 4.3). In contrast, if no Stokes drift or wind is included in the simulation, a large and stable garbage patch forms that spans almost the entire IO basin width. In this case, the simulated concentrations are of the same order as concentrations in the North Pacific subtropical garbage patch.

This behaviour is unique to the IO; the subtropical garbage patches in the Atlantic and Pacific ocean show some minor variation

430 due to different forcing mechanisms but remain stable and in the same region. van der Mheen et al. (2019) suggested that this is a result of the unique dynamics of the southern IO (section 4.2). They specifically state that the strong easterly trade winds in the southern IO as well as the connection with the South Atlantic Ocean (due to the unique geography at this boundary; section 4.2) result in the garbage patch centring towards the west of the basin and leaking into the South Atlantic Ocean if plastics are transported by ocean surface currents, Stokes drift, and wind. If plastics are transported only by ocean currents,

435 van der Mheen et al. (2019) suggested that the garbage patch would span the entire width of the IO basin as a result of the unique South Indian Counter Current (section 4.2) that flows eastwards across the entire width of the basin.

It is however unknown which forcing mechanisms predominantly transport plastics. As a result, it is unclear which of these simulated garbage patches represents best the reality in the subtropical southern IO. Sampling studies in this region are too

440 scarce to provide any conclusions (section 3) about the dimension and the dynamics of plastic amount and the time plastic is contained in the subtropical IO garbage. 


\subsection{Accumulation on coastlines}

Plastics can also beach and accumulate on coastlines. This is most likely to be particularly relevant in the northern IO, as it is surrounded by land on three sides. Reversing ocean surface currents and winds driven by the monsoon system, transport plastics back and forth from the western to the eastern side of the basin (section 4.2), frequently transporting plastics close to coastlines. van der Mheen et al. (2020a) determined beaching patterns of plastics released from river sources in the IO using Lagrangian particle tracking simulations.

The simulation indicated that for plastics entering the northern IO from rivers, coastlines of countries bordering the Bay of Bengal were most affected by beaching plastics (Figure 6). This is most likely due to the large source locations of particles (Figure 1b) and ocean dynamics of the Bay of Bengal. Although there are no downwelling regions in the Bay of Bengal, anticyclonic and cyclonic gyres develop throughout the year (Paul et al., 2009) that may trap plastics. In addition, the annual mean flow along the equator is to the east, directed from the Arabian Sea towards the Bay of Bengal due to the stronger SW monsoon (Schott et al., 2009; de Vos et al., 2014). van der Mheen et al. (2020a) hypothesised that plastics are present in the Bay of Bengal throughout the year (as shown in Figure 5). Countries that were among the top 15 that received the most beached plastics in their simulations were Bangladesh, Myanmar, India, Malaysia, Indonesia, Sri Lanka, Thailand, Pakistan, the Maldives, and Somalia. Of these, only Somalia does not border the Bay of Bengal and does not have significant nearby inputs of plastic waste from rivers. Instead, van der Mheen et al. (2020a) hypothesised that plastics reach Somalia as the North Equatorial Current and Somali Current transport them westwards during the NE monsoon season. Incidentally, all the seven major countries surrounding the Bay of Bengal are believed to have least-managed plastic waste that is prone to enter the sea (Jambeck et al., 2015). The Maldives seemed to have received a relatively large percentage of plastics in the simulations even though it has no riverine plastic sources of its own. They attributed this to the Northeast Monsoon Current and the Southwest Monsoon Current flowing past the Maldives in reversing directions twice a year. Beached plastics have also been found in The Maldives in sampling studies by Imhof et al. (2017).

In the southern IO, countries along the eastern African coast, Madagascar, Mauritius, Réunion, the Cocos (Keeling) Islands, and Christmas Island were heavily affected by beaching plastics from river sources (van der Mheen et al., 2020a). In the simulations, most of these plastics originated from rivers in Indonesia.

470 In many locations mentioned here, studies have sampled beached plastics (section 3). However, a quantitative comparison between studies and model validation is not possible because of the different methods used by these studies. In addition, the simulation results by van der Mheen et al. (2020a) presented here, are simplified, and based on global ocean models. However, the dynamics of beaching plastics is complex and strongly influenced by small-scale coastal ocean dynamics (Isobe et al., 2014), as well as local morphology of the coastline (Zhang, 2017). It is unknown what the influence is of these small-scale 
475 effects on basin-scale beaching patterns in the IO. Finally, plastics do not necessarily remain beached indefinitely, but can also re-float and re-enter the ocean (Zhang, 2017; Lebreton et al., 2019). As a result, it is unknown how much plastic is stored on coastlines in the IO, as well as how permanent this sink is. Thus, long-term (multi-decadal) monitoring and field studies are necessary along IO coastlines.

\section{Impacts}

480 Plastic debris can harm the marine environment, communities, and economies in many different ways. The review by Law (2017) discusses the different harmful effects of plastic debris, as well as existing evidence for their impact in detail. In this section, we briefly discuss different harmful effects of plastic debris and provide more detail about the potential impacts specific to the IO and IO rim countries. In section 6.4, we also provide an overview of the different policies and initiatives that are emerging in IO rim countries to prevent, mitigate, or clean-up plastic debris in the IO.

\section{$485 \quad$ 6.1 Impacts Ghost gear}

Approximately 100 million tonnes of marine capture fishes have been landed globally each year since 2000, approximately $13 \%$ of which originated from the IO (Pauly and Zeller 2016). The IO supports a range of marine ecosystem services including numerous and expansive fishing ventures with $7 \%$, or one million tonnes, of IO landings considered large commercial pelagic fishes, e.g. tuna and billfishes. The commercial pelagic fisheries of the IO alone are worth over US\$ 1300 million annually. Abandoned, lost, and discarded fishing gear (ALDFG; section 4.2) becomes "ghost gear", which continues to entangle and injure or catch wildlife, for decades or centuries as it slowly degrades which additionally increases the pressure on marine wildlife. Entangled and caught fauna of ALDFG starts initially with sea turtles, marine mammals, sharks, and large predators for the first few months, changing to crustaceans when gear fragment into smaller parts (Macfadyen et al., 2009; Wilcox et al., 2015; Stelfox et al., 2016). A single ghost net may decrease fishing revenues by US\$ 20 thousand annually (Lachmann et al., 495 2017) and can consume as much as $30 \%$ of landings within a single fishery (Laist and Liffman, 2000). Although ALDFG is thought to diminish in catching efficiency over time, catching potential of gillnets were estimated to be $20-30 \%$ of original levels for long periods and at least 5\% after more than two years of abandonment (Macfadyen et al., 2009; Stelfox et al., 2016). Some catch rates were estimated to be $81 \mathrm{~kg}$ /day for tangle nets over 1.5 years, an average of $64 \mathrm{~kg} /$ day for deep water gillnets over a 45-day period and 0.6 kg/day for traps left for 3-6 months (Macfadyen et al., 2009).

ALDFG affects the tourism industry through a multitude of factors, including the removal of iconic marine species and wildlife in general, as well as contributing up to $90 \%$ of shoreline debris and degrading of the perceived beauty of an area (Gunn et al., 2010; Lachmann et al., 2017). These devaluations decrease benefits from coral reef tourism (US\$ 36 billion) (Spalding et al., 2017) and global exports of aquarium fish (US\$ 15 billion) (Raja et al., 2019). Ghost gear is also considered to be destructive 
505 to both natural habitats, i.e. coral reefs, and manufactured objects, i.e. boats (Laist and Liffman, 2000; Gunn et al., 2010). Many of the countries bordering the IO are small island developing states (SIDS) where more than $70 \%$ of the population lives along the coast and is highly dependent on marine ecosystem services (Canales et al., 2017). In addition, 60\% of aquarium fish are exported from developing nations (Raja et al., 2019). Thus, the adverse cultural, societal, and sustenance impacts of ghost fishing may disproportionately affect IO rim developing nations (Wong, 2011; Guillotreau et al., 2012; Lachmann et al.,

510 2017).

\subsection{Emerging policies and initiatives on plastic in Indian Ocean rim countries}

Of the top 20 countries ranked by mass in estimated mismanaged plastic waste (MMPW), nine of them are located along the IO rim (Indonesia, India, Thailand, Malaysia, Bangladesh, South Africa, India, Pakistan, and Myanmar). Plastic waste generated by these countries amounts to $\sim 15 \%$ of the worlds' total MMPW (Jambeck et al., 2015), putting pressure on these countries to address the issue of MMPW. Until now, local and national actions have been the primary approach for mitigating plastic pollution (Vince and Hardesty, 2016). The choice of measures at national or local level is left to the IO rim country administrations - in line with the principle of subsidiary. For example, some countries have refundable deposit schemes for bottles (Schuyler et al., 2018). Targeted deposit schemes can help reduce littering and boost recycling and have already helped several countries achieve high collection rates for beverage containers (Lavee, 2010; Dace et al., 2013; Schuyler et al., 2018,).

Several African countries have introduced measures to address plastic bag pollution. In August 2017, Kenya introduced a total ban on plastic bags, banning the use, manufacture, and importation of all plastic bags for commercial and household packaging. Anyone found in violation is subject to a fine of approximately US\$20,000-40,000 and/or one to four years imprisonment, making this ban the toughest in the world. Inland countries such as Botswana, introduced a levy on plastic bags in 2010, while

525 Eritrea banned plastic bags in 2005. Rwanda banned plastic bags in 2008 as part of its Vision 2020 plan for sustainability. In 2007, Uganda introduced a ban of lightweight plastic bags which came into effect that year but was never implemented. Tanzania introduced a ban in 2006 and in South Africa, a bag levy was introduced in 2004 although they were never banned completely.

530 In India, plastic pollution is being fought at various levels, by state governments, NGOs, and individuals across the country. Initiatives range from banning of plastic to beach clean-ups. Several Indian states have banned or regulated the use of plastic, but India still struggles to manage its huge plastic waste. For microplastics, and their presence in consumer goods, regulations are still under development. The National Green Tribunal in January 2017 asked the Union Government to test leading cosmetics brands for microplastics. The Bureau of Indian Standards (BIS) classified microbeads as "unsafe" for use in cosmetic products and banned the use of microbeads in cosmetics in October 2017, but it will only be implemented in 2020. 


\section{Summary}

The Indian Ocean covers $20 \%$ of the Earth's surface and compared to other oceans has unique physical characteristics (northern landmass, connection to the Pacific Ocean through Indonesia, and connection to the Atlantic Ocean past South Africa, Monsoon) that strongly influence the circulation patterns and therefore the fate of plastics. This paper examined the

540 sources, transport, sinks and impacts of plastics in the IO. The main sources of plastics are from rivers (terrestrial sources) with the majority input in the northern Indian Ocean, particularly the Bay of Bengal (Figure 7). There are also land-based sources from Indonesia into the southern Indian Ocean. Inputs from Australia are negligible due to absence of rivers and low population density in Western Australia. In the northern IO, reversing monsoon driven currents transport plastic material between the Bay of Bengal and the Arabian Sea with many plastics making landfall in Somalia, The Maldives, Sri Lanka, east

545 and west coasts of India, Myanmar and western Sumatera (Figure 7). There is no garbage patch in the northern IO however, in the southern IO there is evidence for a garbage patch. However, it is not well defined with very few measurements indicate that it may extend across the whole length of the ocean basin. The main beaching region in the southern IO is the coast of northern Madagascar. There also could be leakage of material into the southern Atlantic Ocean garbage patch past South Africa.

\subsection{Knowledge gaps}

The main gap in knowledge for the IO is the scarcity of data in both the surface and deeper ocean. Only a few data points are available for the whole IO including along coastlines and the deeper ocean (Figure 2). This is a very large constraint, which needs addressing. As demonstrated in this paper, we can simulate the transport of plastics using numerical models but confirmation of these results is of paramount importance. However, the simulations pinpoint to the regions that require 555 attention in future investigations. For example, it is unclear which type of these simulated garbage patches (leaky with low concentrations and on the western side of the IO basin, or stable with high concentrations spanning the entire width of the IO basin) best represents the behaviour of the garbage patch in the subtropical southern IO. For the same reasons, it is also unknown how much plastic is contained in the subtropical IO garbage patch as well as how long it is likely to remain in this garbage patch (both as a result of escaping the IO into the South Atlantic Ocean and as a result of other factors such as sinking 560 and ingestion of plastics).

The main sources of plastics considered in this paper were derived from rivers mainly in the northern Indian Ocean. There is most likely transport of plastics from the from south east Asia through the Indonesian Throughflow (section 4.1). However, these sources are currently undocumented and need to be further investigated.

Considering the importance of increasing plastic pollution, the dynamic pathways and its fate in the marine environment of the Indian Ocean needs further attention. Further, studies on the ingestion of plastic particles and colourants ingestion by 
marine biota, and their residence time in seafood in the marine environment will also be useful for food quality and the overall health of the ecosystem.

The understanding of the exact processes of biofouling, fragmentation, and sinking as well as the timescales on which these occur is limited. As far as we are aware, no studies have focussed on this specific to the IO.

575 Author contribution: All model data analyses were performed by MvdM and SW with supervision by CP. Conceptualization: $\mathrm{CP}$, MvdM; resources: CP; writing - original draft preparation: $\mathrm{CP}$; writing — contributions, review and editing by all authors. All authors have read and agreed to the published version of the manuscript.

Competing interests: The authors declare that the research was conducted in the absence of any commercial or financial 580 relationships that could be construed as a potential conflict of interest.

Special issue statement: This paper is part of the synthesis of the recent results of the 2nd International Indian Ocean Expedition Program (IIOE-2: https://iioe-2.incois.gov.in/).

585 Acknowledgements: MvdM and SH were funded through the University of Western Australia International Postgraduate Research Scholarship, an Australia nPostgraduate Award, and a University Postgraduate Awards. BN was supported by the UKRI funded One Ocean Hub NE/S008950/1. 


\section{References}

Abayomi, O.A., Range, P., Al-Ghouti, M.A., Obbard, J.P., Almeer, S.H., Ben-Hamadou, R., 2017. Microplastics in coastal environments of the Arabian Gulf. Marine Pollution Bulletin 124(1), 181-188. https://doi.org/10.1016/j.marpolbul.2017.07.011.

Abbasi, S., Keshavarzi, B., Moore, F., Turner, A., Kelly, F.J., Dominguez, A.O., Jaafarzadeh, N., 2019. Distribution and potential health impacts of microplastics and microrubbers in air and street dusts from Asaluyeh County, Iran. Environmental Pollution 244, 153-164. https://doi.org/10.1016/j.envpol.2018.10.039.

Akhbarizadeh, R., Moore, F., Keshavarzi, B., Moeinpour, A., 2017. Microplastics and potentially toxic elements in coastal sediments of Iran's main oil terminal (Khark Island). Environmental Pollution 220, $720-731$. https://doi.org/10.1016/j.envpol.2016.10.038

Aliabad, M.K., Nassiri, M., Kor, K., 2019. Microplastics in the surface seawaters of Chabahar Bay, Gulf of Oman (Makran coasts). Marine Pollution Bulletin 143, 125-133. https://doi.org/10.1016/j.marpolbul.2019.04.037.

600 Andrady, A.L., 2011. Microplastics in the marine environment. Marine Pollution Bulletin 62, 1596-1605. https://doi.org/j.marpolbul.2011.05.030.

Arun Kumar, A., Sivakumar, R., Sai Rutwik Reddy, Y., Bhagya Raja, M.V., Nishanth, T., Revanth, V., 2016. Preliminary study on marine debris pollution along Marina beach, Cheannai, India. Regional Studies in Marine Science 5, 35-40, doi: 10.1016/j.rsma.2016.01.002.

Baalkhuyur, F.M., Bin Dohaish, E.J.A., Elhalwagy, M.E.A., Alikunhi, N.M., AlSuwailem, A.M., Røstad, A., Coker, D.J., Berumen, M.L., Duarte, C.M., 2018. Microplastic in the gastrointestinal tract of fishes along the Saudi Arabian Red Sea coast. Marine Pollution Bulletin 131, 407-415. https://doi.org/10.1016/j.marpolbul.2018.04.040.

Baltar, F., Currie, K., Stuck, E., Roosa, S., Morales, S.E., 2016. Oceanic fronts: transition zones for bacterioplankton community composition. Environmental Microbiology Reports 8(1), 132-138. https://doi.org/10.1111/1758-2229.12362.

610 Barnes, D.K.A., 2004. Natural and plastic flotsam stranding in the Indian Ocean. In: J. Davenport and J.L. Davenport, editors, The effects of human transport on ecosystems: cars and planes, boats and trains, Royal Irish Academy, Dublin, pp. 193205.

Barnes, D.K.A., Galgani, F., Thompson, R.C., Barlaz, M., 2009. Accumulation and fragmentation of plastic debris in global environments. Philosophical Transactions of the Royal Society B: Biological Sciences 364(1526), $1985-1998$. https://doi.org/10.1098/rstb.2008.0205.

Beal L.M., de Ruijter, W.P.M, Biastoch, A., Zahn R., 2011. On the role of the Agulhas system in ocean circulation and climate. Nature 472, 429-436. https://doi.org/10.1038/nature09983.

Beaumont, N.J., Aanesen, M., Austen, M.C., Börger, T., Clark, J.R., Cole, M., Hooper, T., Lindeque, P.K., Pascoe, C., Wyles, K.J., 2019. Global ecological, social and economic impacts of marine plastic. Marine Pollution Bulletin 142, $189-195$.

620 Beckman, E., 2018. The world of plastics, in numbers. The Conversation, published: 09-08-2018. https://theconversation.com/the-world-of-plastics-in-numbers-100291.

Belkin, I. M. Cornillon, P. C. 2009. Sherman, K., Fronts in large marine ecosystems. Progress in Oceanography, 81, $223-236$.

Belkin, I.M., Cornillon, P.C., 2007. Fronts in the world ocean's large marine ecosystems. In ICES CM 2007/D:21, International Council for the Exploration of the Sea, pp. 1-33.

625 Bergmann, M., Peeken, I., Beyer, B., Krumpen, T., Primpke, S., Tekman, M.B., Gerdts, G., 2017. Vast quantities of microplastics in Arctic Sea ice - a prime temporary sink for plastic litter and a medium of transport. In: J. Baztan, B. Jorgensen, S. Pahl, R.C. Thompson, and J-P. Vanderlinden, editors, Fate and Impact of Microplastics in Marine Ecosystems, Elsevier, Amsterdam, pp. 75-76. 
Bond, A.L., Montevecchi, W.A., Guse, N., Regular, P.M., Garthe, S., Rail, J-F., 2012. Prevalence and composition of fishing gear debris in the nests of northern gannets (Morus bassanus) are related to fishing effort. Marine Pollution Bulletin 64(5), 907-911.

Bouwman, H., Evans, S.W., Cole, N., Choong Kwet Yive, N.S., Kylin, H., 2016. The flip-or-flop boutique: marine debris on the shores of St Brandon's rock, an isolated tropical atoll in the Indian Ocean. Marine Environmental Research 114, 5864, doi: 10.1016/j.marenvres.2015.12.013.

Brambilla, E., Talley, L.D. 2006. Surface drifter exchange between the North Atlantic subtropical and subpolar gyres, Journal of Geophysical Research: Oceans, 111, C07026, doi:10.1029/2005JC003146.

Breivik, O., Allen, A.A., 2008. An operational search and rescue model for the Norwegian Sea and the North Sea. Journal of Marine Systems 69, 99-113. https://doi.org/10.1016/j.jmarsys.2007.02.010.

Brunner, K., Kukulka, T., Proskurowski, G., Law, K.L., 2015. Passive buoyant tracers in the ocean surface boundary layer: 2. Observations and simulations of microplastic marine debris. Journal of Geophysical Research: Oceans 120. https://doi.org/10.1002/2015JCO10840.

Canales, N., Atteridge, A., Sturesson, A. 2017. Climate finance for the Indian Ocean and African small island developing states. Working paper 2017-11. Stockholm Environment Institute, Stockholm.

Castillo, A.B., Al-Maslamani, I., Obbard, J.P., 2016. Prevalence of microplastics in the marine waters of Qatar. Marine Pollution Bulletin 111(1-2), 260-267. https://doi.org/10.1016/j.marpolbul.2016.06.108.

Courtene-Jones, W., Quinn, B., Ewins, C., Gary, S.F., Narayanaswamy, B.E., 2020. Marine Pollution Bulletin 154, 111092. https://doi.org/10.1016/j.marpolbul.2020.111092.

Courtene-Jones, W., Quinn, B., Gary, S.F., Mogg, A.O.M., Narayanaswamy, B.E., 2017. Microplastic pollution identified in deep-sea water and ingested by benthic invertebrates in the Rockall Trough, north Atlantic Ocean. Environmental Pollution $231,271-280$.

Cózar, A., Echevarria, F., Gonzalez-Gordillo, J.I., Irigoien, X., Ubeda, B., Hernandez-Leon, S., Palma, A.T., Navarro, S., Garcia de Lomas, J., Ruiz, A., Fernandez de Puelles, M.L., Duarte, C.M., 2014. Plastic debris in the open ocean. PNAS 111, 10239-10244. https://doi.org/10.1073/pnas.1314705111.

Crespy, D., Bozonnet, M., Meier, M., 2007. 100 years of bakelite, the material of 1000 uses. Angewandte Chemie International Edition 47, 3322-3328. https://doi.org/10.1002/anie.200704281.

Davison, P., Asch, R.G., 2011. Plastic ingestion by mesopelagic fishes in the North Pacific subtropical gyre. Marine Ecology Progress Series 432, 173-180. https://doi.org/10.3354/meps09142.

Dace E., Pakere I., Blumberga D. 2013. Evaluation of economic aspects of the deposit-refund system for packaging in Latvia. Management of Environmental Quality International Journal 24, 311-329. doi: 10.1108/14777831311322631.

660 D’Asaro E.A., Shcherbina, A.Y. Klymak, J.M., Molemaker, J., Novelli, G., Guigand, C.M., Haza, A.C., Haus, B.K., Ryan, E.H., Jacobs, G.A., Huntley, H.S., Laxague, N.J.M., Chen, S. Judt, F., McWilliams, J.C., Barkan, R., Kirwan, A.D., Poje, A.C., Özgökmen T.M. 2018. Ocean convergence and the dispersion of flotsam, Proceedings of the National Academy of Sciences, 115, 1162-1167; doi:10.1073/pnas.1718453115

de Vos, A., Pattiaratchi, C.B., Wijeratne, E.M.S., 2014. Surface circulation and upwelling patterns around Sri Lanka. Biogeosciences 11(20), 5909-5930.

Dobler, D., Huck, T., Maes, C., Grima, N., Blanke, B., Martinez, E., Ardhuin, F., 2019. Large impact of Stokes drift on the fate of surface floating debris in the South Indian Basin. Marine Pollution Bulletin 148, 202-209. https://doi.org/10.1016/j.marpolbul.2019.07.057. 
Duhec, A.V., Jeanne, R.F., Maximenko, N., Hafner, J., 2015. Composition and potential origin of marine debris stranded in the western Indian Ocean on remote Alphonse Island, Seychelles. Marine Pollution Bulletin 96(1-2), 76-86. https://doi.org/10.1016/j.marpolbul.2015.05.042.

Egger, M., Sulu-Gambari, F., Lebreton, L., 2020. First evidence of plastic fallout from the north Pacific garbage patch. Scientific Reports 10, 7495. https://doi.org/10.1038/s41598-020-64465-8.

Engler, R.E., 2012. The complex interaction between marine debris and toxic chemicals in the ocean. Environmental Science \& Technology 46(22), 12302-12315, doi: 10.1021/es3027105.

Eriksen, M., Lebreton, L.C.M., Carson, H.S., Thiel, M., Moore, C.J., Borerro, J.C., Galgani, F., Ryan, P.G., Reisser, J., 2014. Plastic pollution in the world's oceans: more than 5 trillion plastic pieces weighing over 250,000 tons afloat at sea. PLoS ONE 9(12), e111913, doi:10.1371/journal.pone.0111913.

Eriksen, M., Maximenko, N., Thiel, M., Cummins, A., Lattin, G., Wilson, S., Hafner, J., Zellers, A., Rifman, S., 2013. Plastic pollution in the South Pacific subtropical gyre. Marine Pollution Bulletin 68, 71-76. https://doi.org/10.1016/j.marpolbul.2012.12.021.

Findlater, J., 1969. A major low-level air current near the Indian Ocean during the northern summer. Quarterly Journal of the Royal Meteorological Society 95, 362-380. https://doi.org/10.1002/qj.49709540409.

Freinkel, S., 2011. A brief history of plastic's conquest of the world. Scientific American.

Frias, J.P.G.L., Nash, R., 2019. Microplastics: finding a consensus on the definition. Marine Pollution Bulletin 138, $145-147$. https://doi.org/j.marpolbul.2018.11.022.

Froyland, G., Stuart, R.M., van Sebille, E., 2014. How well-connected is the surface of the global ocean? Chaos 24. https://doi.org/10.1063/1.4892530.

GESAMP (IMO/FAO/UNESCO-IOC/UNIDO/WMO/IAEA/UN/UN Environment/UNDP Joint Group of Experts on the Scientific Aspects of Marine Environmental Protection), 2018. Report of the forty-fourth session of GESAMP, Geneva, Switzerland, 4 to 7 September 2017. Rep. Stud. GESAMP No. 96/GAW Report No. 237, 66 p.

Geyer, R., Jambeck, J.R., Law, K.L., 2017. Production, use, and fate of all plastics ever made. Science Advances 3(7), e1700782, doi: 10.1126/sciadv.1700782.

Gordon, A.L., 2003. The brawniest retroflection. Nature 421, 904-905. https://doi.org/10.1038/421904a.

695 Gregory, M.R., 2009. Environmental implications of plastic debris in marine settings — entanglement, ingestion, smothering, hangers-on, hitch-hiking and alien invasions. Philosophical Transactions of the Royal Society B: Biological Sciences 364 (1526), 2013-2025.

Guillotreau, P., Campling, L., Robinson, J., 2012. Vulnerability of small island fishery economies to climate and institutional changes. Current Opinion in Environmental Sustainability 4(3), 287-291.

700 Gunn, R., Hardesty, B.D., Butler, J., 2010. Tackling 'ghost nets': local solutions to a global issue in northern Australia. Ecological Management \& Restoration 11(2), 88-98.

Guptha, M.V.S., Curry, W.B., Ittekkot, V., Muralinath, A.S., 1997. Seasonal variation in the flux of planktic foraminifera: sediment trap results from the Bay of Bengal, northern Indian Ocean. Journal of Foraminiferal Research 27(1), 5-19. https://doi.org/10.2113/gsjfr.27.1.5.

705 Hajbane, S., Calmanovici, B., Reisser, J., Jolly, A., Summers, V., Ferrari, F., Ghadouani, A., Pattiaratchi, C.B. 2021. Coastal Garbage Patches: Evidence for significant accumulations of buoyant plastics along shallow coastal fronts at Ashmore Reef (Pulau Pasir) Marine Park. Frontiers in Marine Science, (in review).

Hoornweg, D., Bhada-Tata, P., 2012. What a waste: a global review of solid waste management. Technical report, World Bank. Hdl.handle.net/10986/17388. 
710 Imhof, H.K., Sigl, R., Brauer, E., Feyl, S., Giesemann, P., Klink, S., Leupolz, K., Löder, M.G.J., Löschel, L.A., Missun, J., Muszynski, S., Ramsperger, A.F.R.M., Schrank, I., Speck, S., Steibl, S., Trotter, B., Winter, I., Laforsch, C., 2017. Spatial and temporal variation of macro-, meso- and microplastic abundance on a remote coral island of the Maldives, Indian Ocean. Marine Pollution Bulletin 116(1-2), 340-347, doi: 10.1016/j.marpolbul.2017.01.010.

Ismail, M.R., Lewaru, M.W., Prihadi, D.J., 2018. Microplastics ingestion by fish in the Biawak Island. World Scientific News $106,230-237$.

Isobe, A., Kubo, K., Tamura, Y., Kako, S., Nakashima, E., Fujii, N., 2014. Selective transport of microplastics and mesoplastics by drifting in coastal waters. Marine Pollution Bulletin 89, 324-330. https://doi.org/10.1016/j.marpolbul.2014.09.041.

Ittekkot, V., Nair, R.R., Honjo, S., Ramaswamy, V., Bartsch, M., Manginini, S., Desai BN (1996) Enhanced particle fluxes in Bay of Bengal induced by injection of fresh water. Nature 351:385-387.

720 Jambeck, J.R., Geyer, R., Wilcox, C., Siegler, T.R., Perryman, M., Andrady, A., Narayan, R., Law, K.L., 2015. Plastic waste inputs from land into the ocean. Science 347(6223), 768-771, doi: 10.1126/ science.1260352.

Jamieson, A.J., Brooks, L.S.R., Reid, W.D.K., Piertney, S.B., Narayanaswamy, B.E., Linley, T.D., 2019. Microplastics and synthetic particles ingested by deep-sea amphipods in six of the deepest marine ecosystems on Earth. Royal Society Open Science 6(2), art. 180667. https://doi.org/10.1098/rsos.180667.

Jayasiri, H.B., Purushothaman, C.S., Vennila, A., 2013. Plastic litter accumulation on high-water strandline of urban beaches in Mumbai, India. Environmental Monitoring and Assessment 185(9), 7709-7719. https://doi.org/10.1007/s10661-0133129-z.

Joseph, P.V., Sijikumar, S., 2004. Intraseasonal variability of the low-level jetstream of the Asian summer monsoon. Journal of Climate 17, 1449-1458. https://doi.org/10.1175/1520-0442(2004)017<1449:IVOTLJ>2.0.CO;2.

730 Karthik, R., Robin, R.S., Purvaja, R., Ganguly, D., Anandavelu, I., Raghuraman, R., Hariharan, G., Ramakrishna, A., Ramesh, R., 2018. Microplastics along the beaches of southeast coast of India. Science of the Total Environment 645, 1388-1399. https://doi.org/10.1016/j.scitotenv.2018.07.242.

Khalik, W.M.A.W.M., Ibrahim, Y.S., Tuan Anuar, S., Govindasamy, S., Baharuddin, N.F., 2018. Microplastics analysis in Malaysian marine waters: a field study of Kuala Nerus and Kuantan. Marine Pollution Bulletin 135, 451-457. https://doi.org/10.1016/j.marpolbul.2018.07.052.

Koelmans, A.A., Kooi, M., van Sebille, E., 2017. All is not lost: deriving a top-down mass budget of plastic at sea. Environmental Research Letters 12, 1-9. https://doi.org/10.1088/1748-9326/aa9500.

Kooi, M., Nes, E.H., Scheffer, M., Koelmans, A.A., 2017. Ups and downs in the ocean: effects of biofouling on vertical transport of microplastics. Environmental Science \& Technology 51, 7963-7971. https://doi.org/10.1021/acs.est.6b04702.

740 Kooi, M., Reisser, J., Slat, B., Ferrari, F.F., Schmid, M.S., Cunsolo, S., Brambini, R., Noble, K., Sirks, L., Linders, T.E.W., Schoeneich-Argent, R.I., Koelmans, A.A., 2016. The effect of particle properties on the depth profile of buoyant plastics in the ocean. Scientific Reports 6. https://doi.org/10.1038/srep33882.

Koongolla, J.B., Andrady, A.L., Terney Pradeep Kumara, P.B., Gangabadage, C.S., 2018. Evidence of microplastics pollution in coastal beaches and waters in southern Sri Lanka. Marine Pollution Bulletin 137, $277-284$.

745 https://doi.org/10.1016/j.marpolbul.2018.10.031.

Kosore, C., Ojwang, L., Maghanga, J., Kamau, J., Kimeli, A., Omukoto, J., Ngisiag'e, N., Mwaluma, J., Ong'ada, H., Magori, C., Ndirui, E., 2018. Occurrence and ingestion of microplastics by zooplankton in Kenya's marine environment: first documented evidence. African Journal of Marine Science 40(3), $225-234$. https://doi.org/10.2989/1814232X.2018.1492969. 
750 Kukulka, T., Brunner, K., 2015. Passive buoyant tracers in the ocean surface boundary layer: 1. Influence of equilibrium windwaves on vertical distributions. Journal of Geophysical Research: Oceans 120, 3837-3858. https://doi.org/10.1002/2014JC010487.

Kukulka, T., Proskurowski, G., Moret-Ferguson, S., Meyer, D.W., Law, K.L., 2012. The effect of wind mixing on the vertical distribution of buoyant plastic debris. Geophysical Research Letters, 39, https://doi.org/10.1029/2012GL051116.

755 Lachmann, F., Almroth, B.C., Baumann, H., Broström, G., Corvellec, H., Gipperth, L., Hassellöv, M., Karlsson, T., Nilsson, P., 2017. Marine plastic litter on small island developing states (SIDS): impacts and measures. Report no. 2017:4. Swedish Institute for the Marine Environment, University of Gothenburg.

Laist, D.W., Liffman, M., 2000. Impacts of marine debris: research and management needs. In: N. McIntosh, K. Simonds, M. Donohue, C. Brammer, S. Manson, and S. Carbajal, editors, Proceedings of the International Marine Debris Conference on Derelict Fishing Gear and the Ocean Environment, 6-11 August 2000, Honolulu, pp. 344-357.

Lavee D. 2010. A cost-benefit analysis of a deposit-refund program for beverage containers in Israel. Waste Management 30 , 338-345. doi: 10.1016/j.wasman.2009.09.026.

Lambert, E., Le Bars, D., de Ruijter, W.P.M., 2016. The connection of the Indonesian throughflow, south Indian Ocean countercurrent and the Leeuwin current. Ocean Science 12, 771-780. https://doi.org/10.5194/os-12-771-2016.

765 Lavers, J.L., Bond, A.L., 2017. Exceptional and rapid accumulation of anthropogenic debris on one of the world's most remote and pristine islands. PNAS 114, 6052-6055. https://doi.org/10.1073/pnas.1619818114.

Lavers, J.L., Dicks, L., Dicks, M.R., Finger, A., 2019. Significant plastic accumulation on the Cocos (Keeling) Islands, Australia. Scientific Reports 9, art. 7102.

Law, K.L., 2017. Plastics in the marine environment. Annual Review of Marine Science 9, $205-229$. https://doi.org/10.1146/annurev-marine-010816-060409.

Laxague, N.J.M., Ozgokmen, T.M., Haus, B.K., Novelli, G., Shcherbina, A., Sutherland, P., Guigand, C.M., Lund, B., Mancha, S., Alday, M., Molemaker, J., 2017. Observations of near-surface current shear help describe oceanic oil and plastic transport. Geophysical Research Letters 44. https://doi.org/10.1002/2017GL075891.

Lebreton, L., Egger, M., Slat, B., 2019. A global mass budget for positively buoyant microplastic debris in the ocean. Scientific Reports 9. https://doi.org/10.1038/s41598-019-49413-5.

Lebreton, L.C., Greer, S.D., Borrero, J.C., 2012. Numerical modelling of floating debris in the world's oceans. Marine Pollution Bulletin 64, 653-661. https://doi.org/10.1016/j.marpolbul.2011.10.027.

Lebreton, L.C.M., van der Zwet, J., Damsteeg, J-W., Slat, B., Andrady, A., Reisser, J., 2017. River plastic emissions to the world's oceans. Nature Communications 8, art. 15611, doi: 10.1038/ncomms15611.

780 Lutjeharms, J.R.E., 2006. The Agulhas Current retroflection, p. 151. Springer.

Macfadyen, G., Huntington, T., Cappell, R., 2009. Abandoned, lost or otherwise discarded fishing gear. UNEP Regional Seas Reports and Studies no. 185; FAO Fisheries and Aquaculture Technical Paper no. 523, Rome.

Madzena, A., Lasiak, T., 1997. Spatial and temporal variations in beach litter on the Transkei coast of South Africa. Marine Pollution Bulletin 34, 900-907. https://doi.org/10.1016/S0025-326X(97)00052-0.

785 Maes, C., Grima, N., Blanke, B., Martinez, E., Paviet-Salomon, T., Huck, T., 2018. A surface superconvergence pathway connecting the south Indian Ocean to the subtropical south Pacific gyre. Geophysical Research Letters 45. https://doi.org/10.1002/2017GL076366.

Maximenko, N., Hafner, J., Niiler, P., 2012. Pathways of marine debris derived from trajectories of Lagrangian drifters. Marine Pollution Bulletin 65, 51-62. https://doi.org/10.1016/j.marpolbul.2011.04.016. 
790 Meikle, J.L., 1997. American plastic: A cultural history. Rutgers University Press, first paperback edition.

Menezes, V.V., Phillips, H.E., Schiller, A., Bindoff, N.L., Domingues, C.M., Vianna, M.L., 2014. South Indian countercurrent and associated fronts. Journal of Geophysical Research: Oceans 119, 6763-6791. doi: 10.1002/2014JC010076.

Middleton, J.F., Cirano, M., 2002. A northern boundary current along Australia's southern shelves: the Flinders current. Journal of Geophysical Research 107, 1-11. https://doi.org/10.1029/2000JC000701.

Moore, C.J., Moore, S.L., Leecaster, M.K., Weisberg, S.B., 2001. A comparison of plastic and plankton in the North Pacific central gyre. Marine Pollution Bulletin 42, 1297-1300. https://doi.org/10.1016/S0025-326X(01)00114-X.

Morris, R.J., 1980. Plastic debris in the surface waters of the South Atlantic. Marine Pollution Bulletin 11, $164-166$. https://doi.org/10.1016/0025-326X(80)90144-7.

Nahas EL, Pattiaratchi CB \& Ivey GN. 2005. Processes controlling the position of frontal systems in Shark Bay, Western Australia. Estuarine, Coastal and Shelf Science, 65(3), 463-474.

Naidu, S.A., 2019. Preliminary study and first evidence of presence of microplastics and colorants in green mussel, Perna viridis (Linnaeus, 1758), from southeast coast of India. Marine Pollution Bulletin 140, 416-422. https://doi.org/10.1016/j.marpolbul.2019.01.024.

Naidu, S.A., Ranga Rao, V., Ramu, K., 2018. Microplastics in the benthic invertebrates from the coastal waters of Kochi, southeastern Arabian Sea. Environmental Geochemistry and Health 40(4), 1377-1383. https://doi.org/10.1007/s10653017-0062-z.

Naji, A., Nuri, M., Vethaak, A.D., 2018. Microplastics contamination in molluscs from the northern part of the Persian Gulf. Environmental Pollution 235, 113-120. https://doi.org/10.1016/j.envpol.2017.12.046.

Nel, H.A., Froneman, P.W., 2015. A quantitative analysis of microplastic pollution along the south-eastern coastline of South Africa. Marine Pollution Bulletin 101(1), 274-279.

Nor, N.H.M., Obbard, J.P., 2014. Microplastics in Singapore's coastal mangrove ecosystems. Marine Pollution Bulletin 79(12), 278-283. Obbard, R.W., Sadri, S., Wong, Y.Q., Khitun, A.A., Baker, I., Thompson, R.C., 2014. Global warming releases microplastic legacy frozen in Arctic Sea ice. AGU Earth's Future. https://doi.org/10.1002/2014EF000240.

Obbard, R.W., S. Sadri, Y.Q. Wong, A.A. Khitun, I. Baker, and R.C. Thompson 2014. Global warming releases microplastic legacy frozen in Arctic Sea ice. Earth's Future, 2, 315-320, https://doi.org/10.1002/2014EF000240.

Owen, R.W., 1981. Fronts and eddies in the sea: mechanisms, interactions and biological effects. In: A.R. Longhurst, editor, Analysis of Marine Ecosystems, Academic Press, London, pp. 197-233.

Palastanga, V., van Leeuwen, P.J., Schouten, M.W., de Ruijter, W.P.M., 2007. Flow structure variability in the subtropical Indian Ocean: instability of the south Indian Ocean countercurrent. Journal of Geophysical Research 112, C01001. https://doi.org/10.1029/2005JC003395.

Pattiaratchi, C., Woo, M., 2009. The mean state of the Leeuwin current system between North West Cape and Cape Leeuwin. Journal of the Royal Society of Western Australia 92, 221-241.

Paul, S., Chakraborty, A., Pandey, P.C., Basu, S., Satsangi, S.K., Ravichandran, M., 2009. Numerical simulation of Bay of Bengal circulation features from ocean general circulation model. Marine Geodesy 32, 1-18. https://doi.org/10.1080/01490410802661930.

Pauly, D., Zeller, D., 2016. Catch reconstructions reveal that global marine fisheries catches are higher than reported and declining. Nature Communications 7, art. 10244. https://doi.org/10.1038/ncomms10244.

Peeken, I., Primpke, S., Beyer, B., Gütermann, J., Katlein, C., Krumpen, T., Bergmann, M., Hehemann, L., Gerdts, G., 2018. Arctic sea ice is an important temporal sink and means of transport for microplastic. Nature Communications 9, art. 1505. https://doi.org/10.1038/s41467-018-03825-5. 
PlasticsEurope, 2019. Plastics the facts 2019 - An analysis of European plastics production, demand and waste data. Technical report, PlasticsEurope.

Qasim, S.Z. 1977. Contribution of zooplankton in food chains of some warm water environment. In: Proceedings of the symposium on Warm Water Zooplankton, National Institute of Oceanography, Goa, 700-708 pp.

Qui, Y., Yu, W., 2009. Behaviour of the Wrytki jet observed with surface drifting buoys and satellite altimeter. Geophysical Research Letters 36, 1-5. https://doi.org/10.1029/2009GL039120.

Raja, K., Aanand, P., Padmavathy, S., Sampathkumar, J.S., 2019. Present and future market trends of Indian ornamental fish sector. International Journal of Fisheries and Aquatic Studies 7(2), 6-15.

Raynaud, J., 2014. Valuing Plastic: The Business Case for Measuring, Managing and Disclosing Plastic Use in the Consumer Goods Industry. UNEP.

Readman, J.W., DeLuna, F., Ebinghaus, R., Guzman, A.N., Price, A.R.G., Readman, E.E., Sheppard, A.L.S., Sleight, V.A., Sturm, R., Thompson, R.C., Tonkin, A., Wolschke, H., Wright, R.J., Sheppard, C.R.C., 2013. Contaminants, pollution and potential anthropogenic impacts in Chagos/BIOT. In: C.R.C. Sheppard, editor, Coral Reefs of the United Kingdom Overseas Territories. Coral Reefs of the World, vol 4, Springer, Dordrecht, https://doi.org/10.1007/978-94-007-5965-7_21.

845 Reddy, M.S., Basha, S., Adimurthy, S., Ramachandraiah, G., 2006. Description of the small plastics fragments in marine sediments along the Alang-Sosiya ship-breaking yard, India. Estuarine, Coastal and Shelf Science 68(3-4), 656-660.

Reisser, J., Shaw, J., Wilcox, C., Hardesty, B.D., Proietti, M., Thums, M., Pattiaratchi, C., 2013. Marine plastic pollution in waters around Australia: characteristics, concentrations, and pathways. PLoS ONE 8. https://doi.org/10.1371/journal.pone.0080466.

850 Reisser, J., Slat, B., Noble, K., du Plessis, K., Epp, M., Proietti, M., de Sonneville, J., Becker, T., Pattiaratchi, C., 2015. The vertical distribution of buoyant plastics at sea: an observational study in the North Atlantic gyre. Biogeosciences 12, 12491256. https://doi.org/10.5194/bg-12-1249-2015.

Richardson, K., Hardesty, B.D., Wilcox, C., 2019. Estimates of fishing gear loss rates at a global scale: a literature review and meta-analysis. Fish and Fisheries 20, 1218-1231. https://doi.org/10.1111/faf.12407.

855 Richardson, P.L., 1997. Drifting in the wind: leeway error in shipdrift data. Deep Sea Research 44, $1877-1903$. https://doi.org/10.1016/S0967-0637(97)00059-9.

Robin, R.S., Karthik, R., Purvaja, R., Ganguly, D., Anandavelu, I., Mugilarasan, M., Ramesh, R., 2020. Holistic assessment of microplastics in various coastal environmental matrices, southwest coast of India. Science of the Total Environment 703, 134947. https://doi.org/10.1016/j.scitotenv.2019.134947.

860 Rochman, C.M., Hoh, E., Hentschel, B.T., Kaye, S., 2012. Long-term field measurements of sorption of organic contaminants to five types of plastic pellets: implications for plastic marine debris. Environmental Science and Technology 47, 16461654. https://doi.org/10.1021/es303700s.

Röhrs, J., Christensen, K.H., Hole, L.R., Brostrom, G., Drivdal, M., Sundby, S., 2012. Observation-based evaluation of surface wave effects on currents and trajectory forecasts. Ocean Dynamics 62, 1519-1533. https://doi.org/10.1007/s10236-0120576-y.

Roy, R., Chitari, R., Kulkarni, V., Krishna, M.S., Sarma, V.V.S.S., Anil, A.C., 2015. CHEMTAX-derived phytoplankton community structure associated with temperature fronts in the northeastern Arabian Sea. Journal of Marine Systems 144, $81-91$.

Ryan, P.G., 1987. The origin and fate of artefacts stranded on islands in the African sector of the Southern Ocean. Environmental Conservation 14, 341-346. https://doi.org/10.1017/ S0376892900016854. 
Saliu, F., Montano, S., Garavaglia, M.G., Lasagni, M., Seveso, D., Galli, P., 2018. Microplastic and charred microplastic in the Faafu Atoll, Maldives. Marine Pollution Bulletin 136, 464-471. https://doi.org/10.1016/j.marpolbul.2018.09.023.

Saliu, F., Montano, S., Leoni, B., Lasagni, M., Galli, P., 2019. Microplastics as a threat to coral reef environments: detection of phthalate esters in neuston and scleractinian corals from the Faafu Atoll, Maldives. Marine Pollution Bulletin 142, 234241. https://doi.org/10.1016/j.marpolbul.2019.03.043.

Sarijan, S., Azman, S., Said, M.I.M., Andu, Y., Zon, N.F., 2018. Microplastics in sediment from Skudai and Tebrau river, Malaysia: a preliminary study. MATEC Web of Conferences 250, art. 06012. https://doi.org/10.1051/matecconf/201825006012.

Sarkar, K., Aparna, S.G., Dora, S., Shankar, D., 2018. Seasonal variability of sea-surface temperature fronts associated with large marine ecosystems in the north Indian Ocean. Journal of Earth System Science 128, 1-8. https://doi.org/10.1007/s12040-018-1045-X

Sarma, V.V.S.S., Delabehra, H.B., Sudharani, P., Remya, R., Patil, J.S., Desai, D.V., 2015. Variations in the inorganic carbon components in the thermal fronts during winter in the northeastern Arabian Sea. Marine Chemistry 169, 16-22. https://doi.org/10.1016/j.marchem.2014.12.009.

885 Sathish, N., Jeyasanta, K.I., Patterson, J., 2019. Abundance, characteristics and surface degradation features of microplastics in beach sediments of five coastal areas in Tamil Nadu, India. Marine Pollution Bulletin 142, 112-118.

Schmidt, C., Krauth, T., Wagner, S., 2017. Export of plastic debris by rivers into the sea. Environmental Science and Technology 51, 12246-12253. https://doi.org/10.1021/acs.est.7b02368.

Schmidt, C., Krauth, T., and Wagner, S., 2018. Correction to export of plastic debris by rivers into the sea. Environmental Science and Technology 52, 927. https://doi.org/10.1021/acs.est.7b06377.

Schott, F.A., McCreary, J.P., 2001. The monsoon circulation of the Indian Ocean. Progress in Oceanography 51, 1-123. https://doi.org/10.1016/S0079-6611(01)00083-0.

Schott, F.A., Xie S.P., McCreary J.P., 2009. Indian Ocean circulation and climate variability. Reviews of Geophysics, 47. https://doi.org/10.1029/2007RG000245.

895 Schuyler Q., Hardesty B.D., Lawson T.J., Opie K., Wilcox C. 2018. Economic incentives reduce plastic inputs to the ocean. Marine Policy 96, 250-255. doi: 10.1016/j.marpol.2018.02.009.

Seth, C.K., Shriwastav, A., 2018. Contamination of Indian sea salts with microplastics and a potential prevention strategy. Environmental Science and Pollution Research 25, 30122-30131. https://doi.org/10.1007/s11356-018-3028-5.

Seymour, R.B., Kauffman, G.B., 1993. The rise and fall of celluloid. Products of Chemistry 69, 311-314. https://doi.org/10.1021/ed069p311.

Shankar, D., Shetye, S.R., 1997. On the dynamics of the Lakshadweep high and low in the southeastern Arabian Sea. Journal of Geophysical Research: Oceans 102(C6), 12551-12562. https://doi.org/10.1029/97JC00465.

Sheavly, S.B., Register, K.M., 2007. Marine debris \& plastics: environmental concerns, sources, impacts and solutions. Journal of Polymers and the Environment 15, 301-305.

905 Shenoi, S.S.C., Shankar, D., Shetye, S.R., 2004. Remote forcing annihilates barrier layer in southeastern Arabian Sea. Geophysical Research Letters 31(5), L05307, doi: 10.1029/2003GL019270.

Slip, D.J., Burton, H.R., 1991. Accumulation of fishing debris, plastic litter, and other artefacts, on Heard and Macquarie islands in the Southern Ocean. Environmental Conservation 18, 249-254. https://doi.org/10.1017/ S0376892900022177.

Spalding, M., Burke, L., Wood, S.A., Ashpole, J., Hutchison, J., zu Ermgassen, P., 2017. Mapping the global value and distribution of coral reef tourism. Marine Policy 82, 104-113. 
Sprintall, J., Wijffels, S.E., Molcard, R., Jaya, I., 2009. Direct estimates of the Indonesian throughflow entering the Indian Ocean: 2004-2006. Journal of Geophysical Research: Oceans 114, 1-19. https://doi.org/10.1029/2008JC005257.

Sprintall, J., Wijffels, S., Molcard, R., Jaya, I., 2010. Direct evidence of the South Java current system in Ombai Strait. Dynamics of Atmospheres and Oceans 50, 140-156. https://doi.org/ 10.1016/j.dynatmoce.2010.02.006.

915 Sruthy, S., Ramasamy, E. V., 2016. Microplastic pollution in Vembanad Lake, Kerala, India: The first report of microplastics in lake and estuarine sediments in India. Environmental Pollution 222, 315-322. https://doi.org/10.1016/j.envpol.2016.12.038

Stelfox, M., Hudgins, J., Sweet, M., 2016. A review of ghost gear entanglement amongst marine mammals, reptiles and elasmobranchs. Marine Pollution Bulletin 111(1-2), 6-17.

920 Stramma, L., Fischer, J., Schott, F., 1996. The flow field off southwest India at $8 \mathrm{~N}$ during the southwest monsoon of August 1993. Journal of Marine Research 54(1), 55-72. https://doi.org/10.1357/0022240963213448.

Syakti, A.D., Bouhroum, R., Hidayati, N.V., Koenawan, C.J., Boulkamh, A., Sulistyo, I., Lebarillier, S., Akhlus, S., Doumenq, P., Wong-Wah-Chung, P., 2017. Beach macro-litter monitoring and floating microplastic in a coastal area of Indonesia. Marine Pollution Bulletin 122(1-2), 217-225. https://doi.org/10.1016/j.marpolbul.2017.06.046.

925 Talley L.D., Pickard, G.L., Emery, W.J., Swift, J.H. 2011. Descriptive physical oceanography: An Introduction. $6^{\text {th }}$ Edition. Academic Press, New York.

Taylor, M.L., Gwinnett, C., Robinson, L.F., Woodall, L.C., 2016. Plastic microfibre ingestion by deep-sea organisms. Scientific Reports 6, art. 33997. https://doi.org/10.1038/srep33997.

Thushari, G.G.N., Senevirathna, J.D.M., Yakupitiyage, A., Chavanich, S., 2017. Effects of microplastics on sessile invertebrates in the eastern coast of Thailand: an approach to coastal zone conservation. Marine Pollution Bulletin 124(1), $349-355$.

Tomczak, M., and Godfrey, J. S.: Regional oceanography: An introduction, 2 ed., Pergamon, 2003.

Uneputty, P.A., Evans, S.M., 1997. Accumulation of beach litter on islands of the Pulau Seribu Archipelago, Indonesia. Marine Pollution Bulletin 34, 652-655. https://doi.org/10.1016/S0025-326X(97)00006-4.

935 Van Cauwenberghe, L., Vanreusel, A., Mees, J., Janssen, C.R., 2013. Microplastic pollution in deep-sea sediments. Environmental Pollution 182, 495-499.

van der Mheen, M., Pattiaratchi, C., van Sebille, E., 2019. Role of Indian Ocean dynamics on accumulation of buoyant debris. Journal of Geophysical Research: Oceans 124(4). https://doi.org/10.1029/2018JC014806.

van der Mheen, M., 2020a. Chapter 6: Escape pathways for buoyant debris from the Indian Ocean. Transport and accumulation of buoyant marine plastic debris in the Indian Ocean. $\mathrm{PhD}$ thesis, the University of Western Australia. https://doi.org/10.26182/x6a8-9r24.

van der Mheen, M., Pattiaratchi, C., Cosoli, S., Wandres, M., 2020b. Depth-dependent correction for wind-driven drift current in particle tracking applications. Frontiers in Marine Science 7. https://doi.org/10.3389/fmars.2020.00305.

van der Mheen, M., van Sebille, E., Pattiaratchi, C.B., 2020c. Beaching patterns of plastic debris along the Indian Ocean rim. Ocean Science 16, 1317-1336. https://doi.org/10.5194/os-16-1317-2020.

van Franeker, J.A., 2011. Reshape and relocate: seabirds as transformers and transporters of microplastics. NOAA Technical Memorandum, NOS-OR\&R, 278-280.

van Sebille, E., Aliani, S., Law, K.L., Maximenko, N., Alsina, J.M., Bagaev, A., Bergmann, M., Chapron, B., Chubarenko, I., Cózar, A., Delandmeter, P., Egger, M., Fox-Kemper, B., Garaba, S.P., Goddijn-Murphy, L., Hardesty, B.D., Hoffman, M.J., Isobe, A., Jongedijk, C.E., Kaandorp, M.L.A., Khatmullina, L., Koelmans, A.A., Kukulka, T., Laufkötter, C., Lebreton, L., Lobelle, D., Maes, C., Martinez-Vicente, V., Maqueda, M.A.M., Poulain-Zarcos, M., Rodriguez, E., Ryan, 
P.G., Shanks, A.L., Shim, W.J., Suaria, G., Thiel, M., van den Bremer, T.S., Wichmann, D., 2020. The physical oceanography of the transport of floating marine debris. Environmental Research Letters 15, 023003, https://doi.org/10.1088/1748-9326/ab6d7d. surface drifters. Environmental Research Letters 7, 044040. https://doi.org/10.1088/1748-9326/7/4/044040.

van Sebille, E., Wilcox, C., Lebreton, L., Maximenko, N., Hardesty, B.D., van Franeker, J.A., Eriksen, M., Siegel, D., Galgani, F., Law, K.L., 2015. A global inventory of small floating plastic debris. Environmental Research Letters 10, 124006. https://doi.org/10.1088/1748-9326/10/12/124006.

960 Veerasingam, S., Mugilarasan, M., Venkatachalapathy, R., Vethamony, P., 2016a. Influence of 2015 flood on the distribution and occurrence of microplastic pellets along the Chennai coast, India. Marine Pollution Bulletin 109(1), 196-204. https://doi.org/10.1016/j.marpolbul.2016.05.082.

Veerasingam, S., Saha, M., Suneel, V., Vethamony, P., Rodrigues, A.C., Bhattacharyya, S., Naik, B.G., 2016b. Characteristics, seasonal distribution and surface degradation features of microplastic pellets along the Goa coast, India. Chemosphere 159, 496-505.

Vince J., Hardesty B.D. 2016. Plastic pollution challenges in marine and coastal environments: From local to global governance. Restoration Ecology 25, 123-128. doi: 10.1111/rec.12388.

Wijeratne, S., Pattiaratchi, C., Proctor, R., 2018. Estimates of surface and subsurface boundary current transport around Australia. Journal of Geophysical Research: Oceans 123. https://doi.org/10.1029/2017JC013221.

970 Wilcox, C., Heathcote, G., Goldberg, J., Gunn, R., Peel, D., Hardesty, B.D., 2015. Understanding the sources and effects of abandoned, lost, and discarded fishing gear on marine turtles in northern Australia. Conservation Biology 29(1), $198-206$.

Wong, P.P., 2011. Small island developing states. WIREs Climate Change 2(1), 1-6.

Woodall, L.C., Sanchez-Vidal, A., Canals, M., Paterson, G.L.J., Coppock, R., Sleight, V., Calafat, A., Rogers, A.D., Narayanaswamy, B.E., Thompson, R.C., 2014. The deep sea is a major sink for microplastic debris. Royal Society Open Science 1(4), 140317. https://doi.org/10.1098/rsos.140317.

Woodson, C.B., Litvin, S.Y., 2015. Ocean fronts drive marine fishery production and biogeochemical cycling. Proceedings of the National Academy of Sciences of the United States of America 112(6), 1710-1715. https://doi.org/10.1073/pnas.1417143112.

Wyrtki, K., 1973. An equatorial jet in the Indian Ocean. Science 181, 262-264. https://doi.org/10.1126/science.181.4096.262.

980 Zhang, H., 2017. Transport of microplastics in coastal seas. Estuarine, Coastal and Shelf Science 199, 74-86. https://doi.org/10.1016/j.ecss.2017.09.032. 


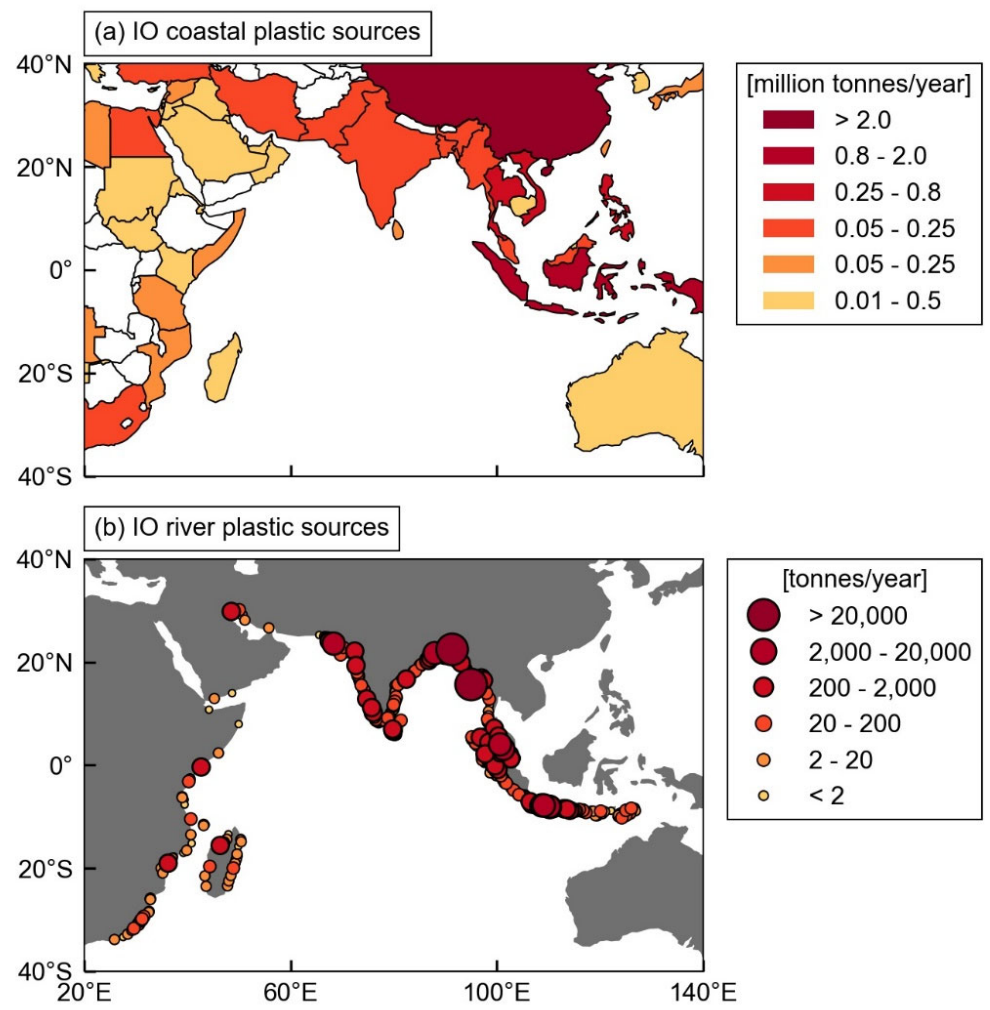

Figure 1: (a) Estimated coastal sources of plastic waste entering the Indian Ocean, based on data from Jambeck et al. (2015). Plastic waste input estimates for Sri Lanka have been reduced by a factor of 10 in this map to correct for a mistake in Jambeck et al's. (2015) data. (b) Estimated river sources of plastic waste entering the Indian Ocean, based on data from Lebreton et al. (2017). Note that the riverine inputs from Australia is negligible due to lack of major rivers. 

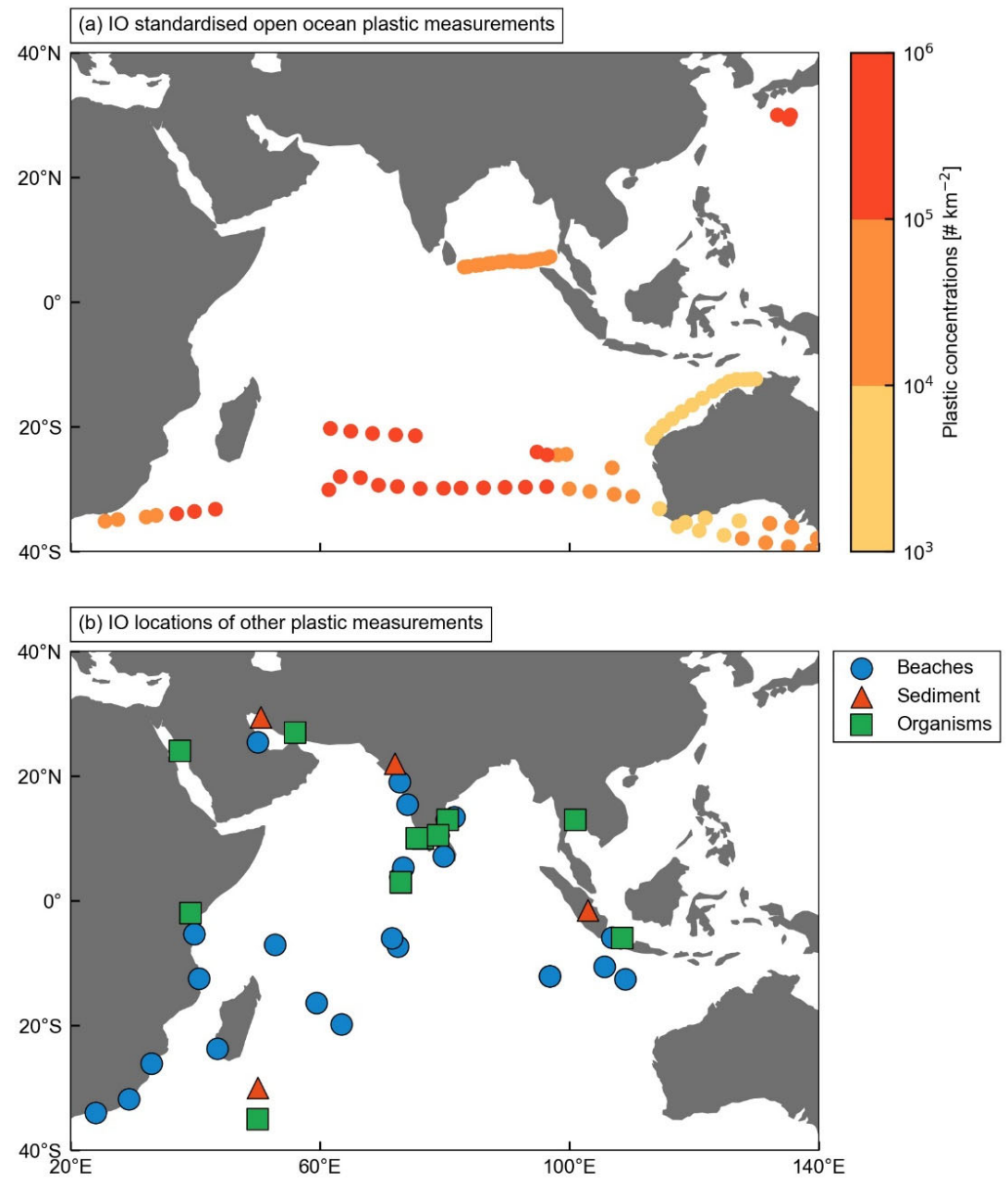

Figure 2. (a) Standardised measured concentrations of plastics in the Indian Ocean. Original samples were performed by Morris (1980); Reisser et al, (2013); Eriksen et al, (2014); Cózar et al (2014) and were standardised by van Sebille et al, (2015). (b) Locations of plastic samples taken on beaches, in sediment, and in organisms around the Indian Ocean (references to individual studies listed in Table 1). Because sampling methods vary widely between studies, a quantitative comparison of measured plastic concentrations between these studies is not possible. 

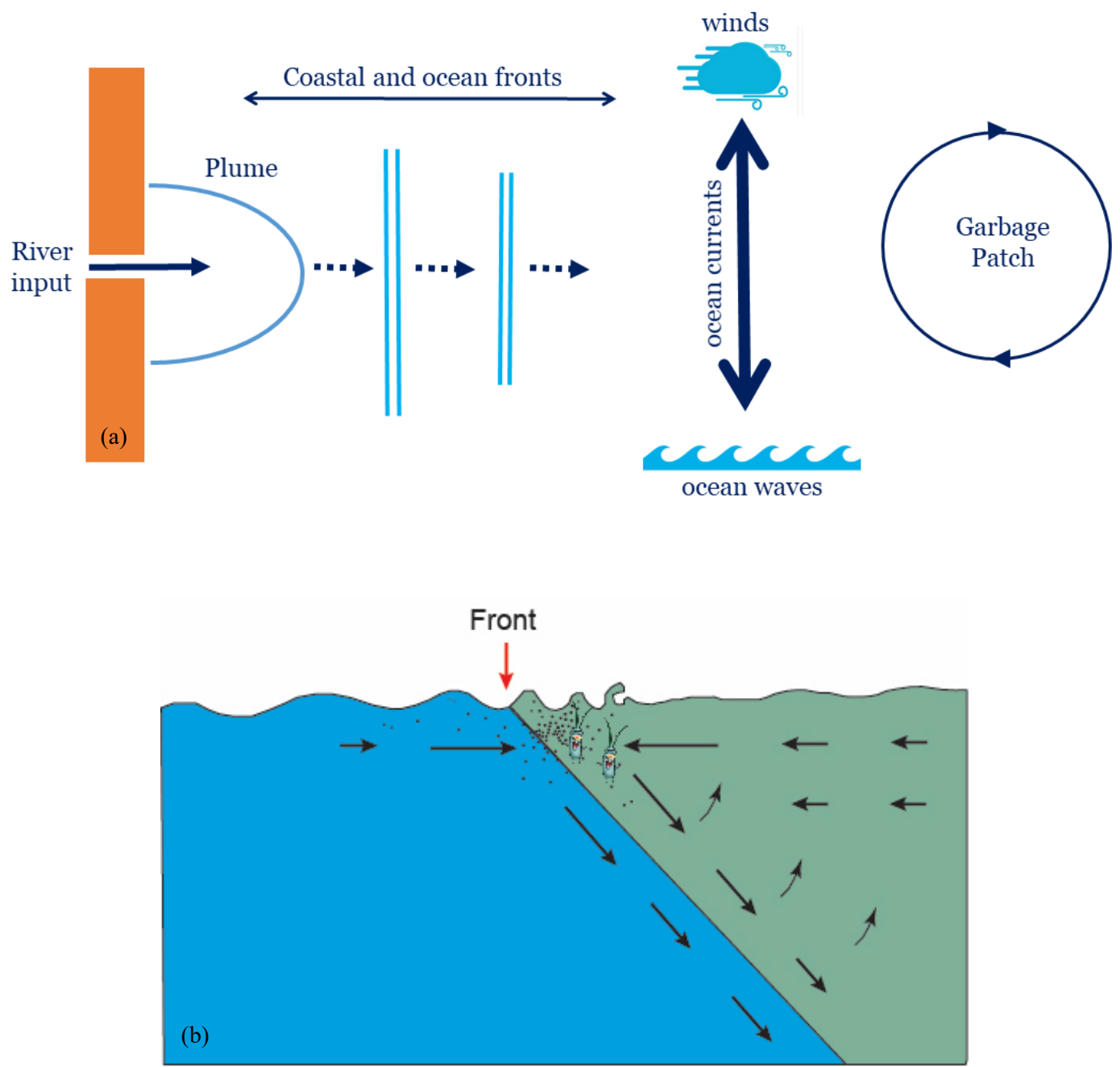

Figure 3. Schematic illustrating the different physical processes that control the transport of buoyant material from rivers to the open ocean (not to scale): (a) birds eye view; (b) cross-section showing convergence at the front and aggregation of buoyant material. 1010 

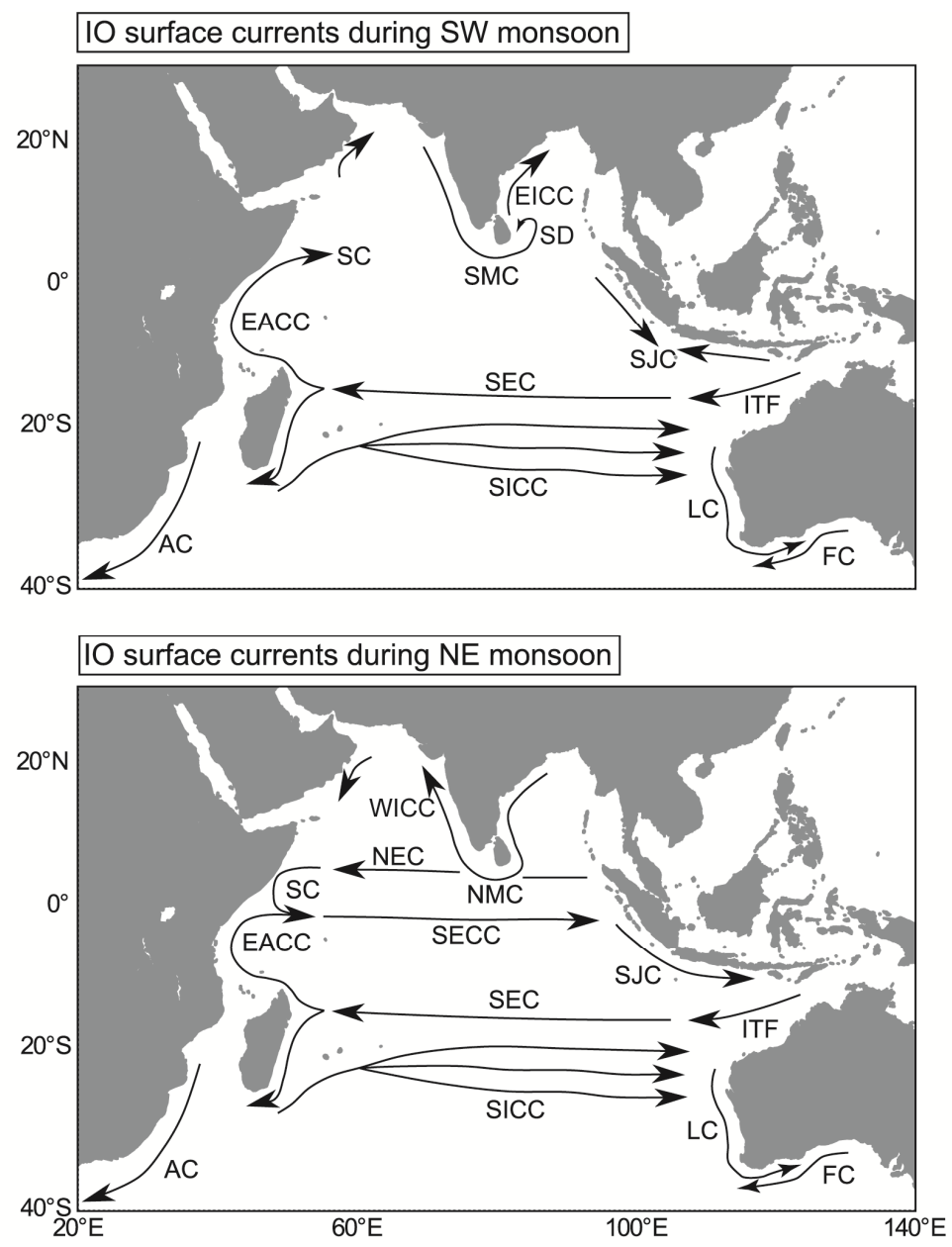

1015 Figure 4. Schematic of ocean surface currents in the Indian Ocean based on Schott et al. (2009), during (a) the SW monsoon season; and (b) the NE monsoon season. The following currents are shown and labelled with abbreviations: Southwest Monsoon Current (SMC) and Northeast Monsoon Current (NMC); West Indian Coastal Current (WICC) and East Indian Coastal Current (EICC); Sri Lanka Dome (SLD); South Java Current (SJC); Indonesian Throughflow (ITF); Somali Current (SC); East African Coastal Current (EACC); North Equatorial Current (NEC); South Equatorial Counter Current (SECC); South Equatorial Current (SEC); 1020 Agulhas Current (AC); Leeuwin Current (LC); Flinders Current (FC); and South Indian Counter Current (SICC). 

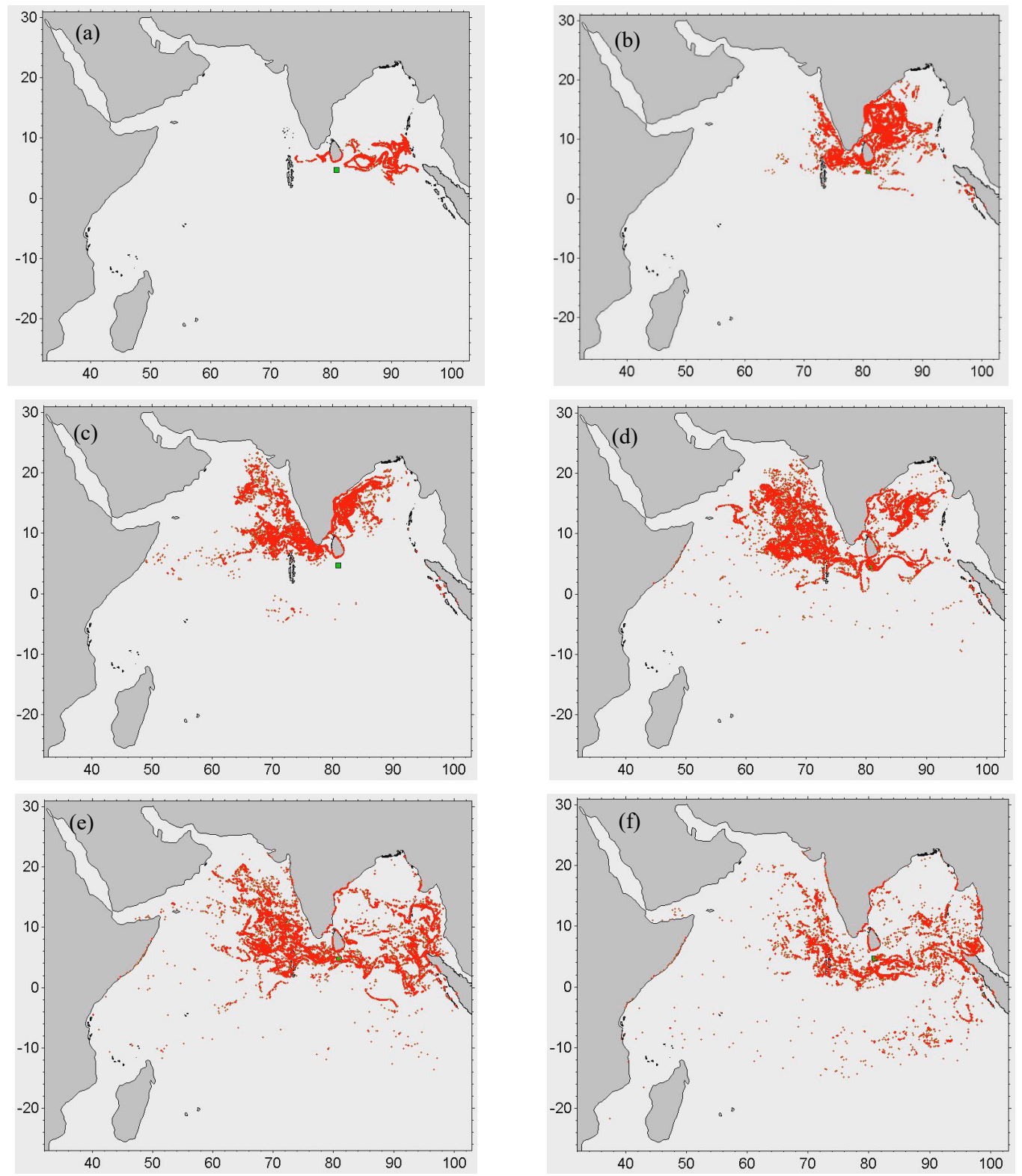

Figure 5 - Results of particle tracking in the northern Indian ocean. 10,000 particles were released on 1 September to the south of Sri Lanka (green square) and tracked using hourly surface current output from HYCOM model. (a) 1 November; (b) 1 January; (c) 1 March; (d) 1 May; (e) 1 July; (f) 1 September. 
https://doi.org/10.5194/os-2020-127

Preprint. Discussion started: 11 February 2021

(c) Author(s) 2021. CC BY 4.0 License.

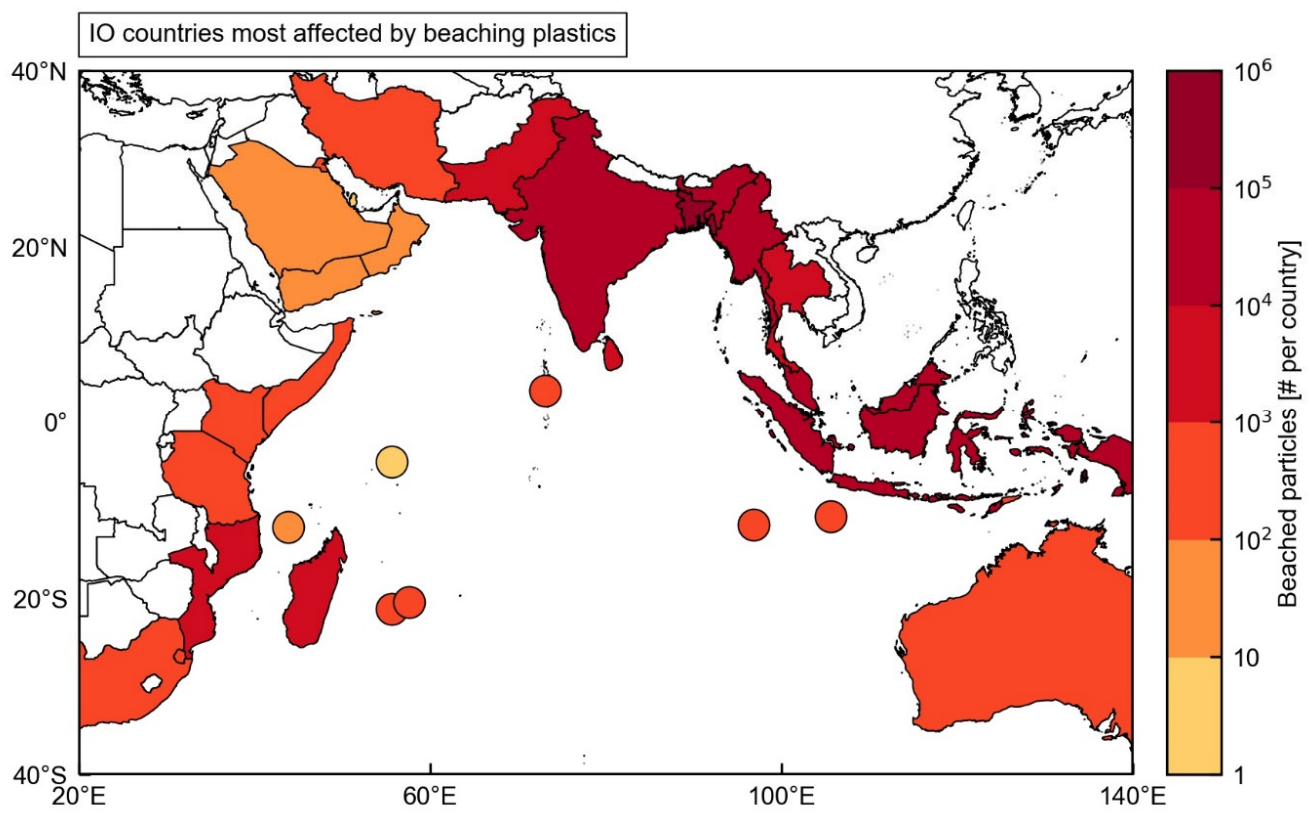

Figure 6. Countries and islands in the Indian Ocean most affected by beaching plastics from river sources. Colours show the number of particles that have beached in each country in Lagrangian particle tracking simulations by van der Mheen et al. (2020a), where particles beach with a $50 \%$ chance if they come within $8 \mathrm{~km}$ of a coastline. Figure adapted from van der Mheen et al. (2020a). 
https://doi.org/10.5194/os-2020-127

Preprint. Discussion started: 11 February 2021

(c) Author(s) 2021. CC BY 4.0 License.

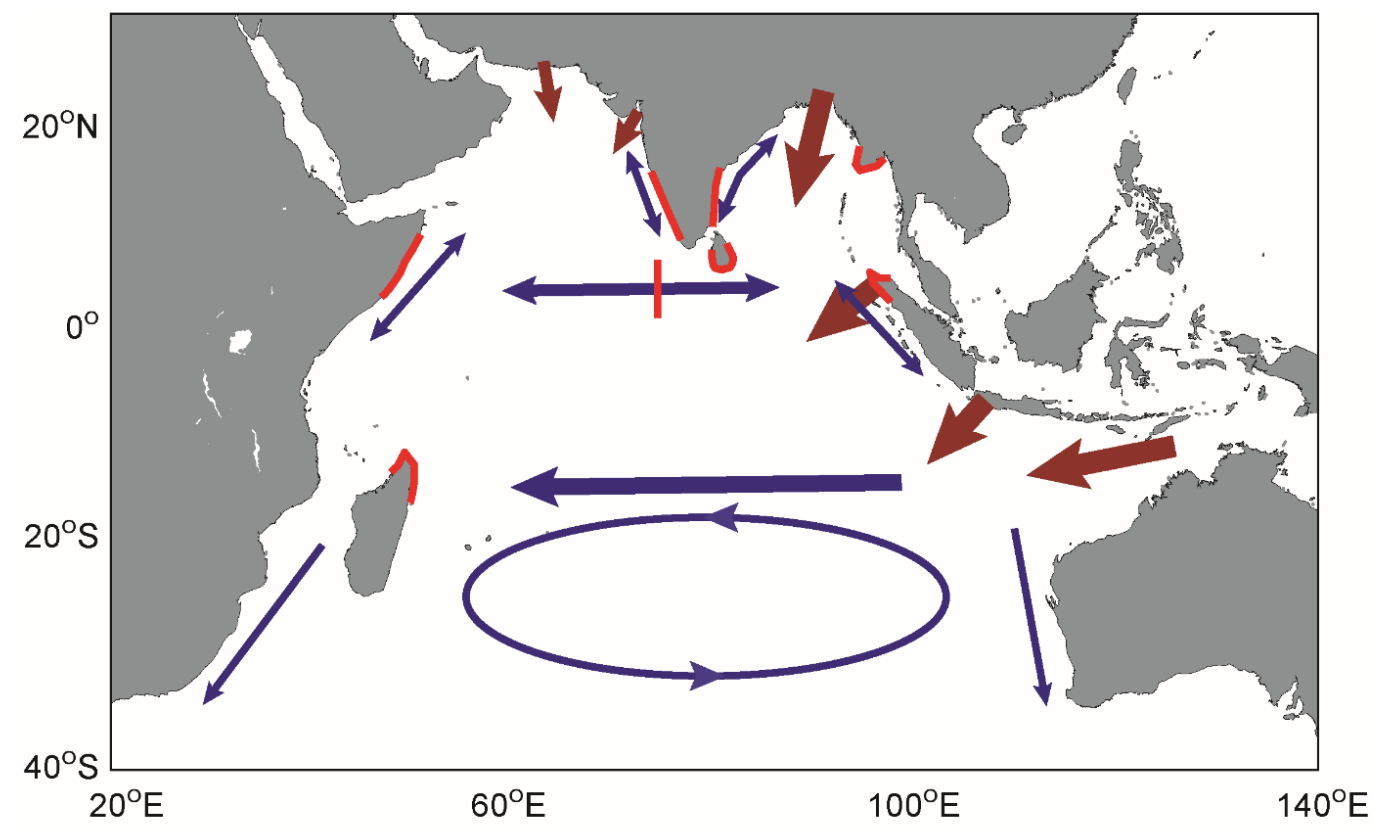

1035 Figure 7. Schematic showing major plastic sources (brown arrows); plastic transport pathways (blue arrows); and major beaching locations of plastics (red regions) in the Indian Ocean. 
1040 Table 1. Overview of plastic sampling studies performed in the Indian Ocean.

\begin{tabular}{|c|c|c|c|c|c|c|c|}
\hline \multirow{2}{*}{ Location } & \multirow{2}{*}{$\begin{array}{c}\text { Latitud } \\
\text { e } \\
{\left[{ }^{\circ} \mathrm{N}\right]}\end{array}$} & \multirow{2}{*}{$\begin{array}{c}\text { Longitud } \\
\text { e } \\
{\left[{ }^{\circ} \mathbf{E}\right]}\end{array}$} & \multirow{2}{*}{$\begin{array}{c}\text { Observation } \\
\text { s }\end{array}$} & \multicolumn{3}{|c|}{ Categories* } & \multirow{2}{*}{ Reference } \\
\hline & & & & $\begin{array}{l}\text { Size } \\
{[\mathrm{mm}]}\end{array}$ & $\begin{array}{l}\text { Shape/ty } \\
\text { pe }\end{array}$ & Polymers & \\
\hline $\begin{array}{l}\text { The Chagos } \\
\text { Archipelago, Chagos } \\
\text { (BIOT) }\end{array}$ & -6 & 71.5 & Beaches & {$[0.03,4]$} & $\begin{array}{l}\text { fragments, } \\
\text { fibres }\end{array}$ & $\begin{array}{l}\text { NY, PE, } \\
\text { PES, PP, } \\
\text { RY }\end{array}$ & $\begin{array}{l}\text { Readman et al., } \\
2013\end{array}$ \\
\hline $\begin{array}{l}\text { Seamounts, } \\
\text { Southwest Indian } \\
\text { Ocean }\end{array}$ & -30 & {$[40,60]$} & Sediment & {$[2,3]$} & fibres & $\begin{array}{l}\text { RY, ACT, } \\
\text { ACR, PES, } \\
\text { PA }\end{array}$ & $\begin{array}{l}\text { Woodall et al., } \\
2014\end{array}$ \\
\hline $\begin{array}{l}\text { Southwest Indian } \\
\text { Ocean }\end{array}$ & {$[-40,-30]$} & {$[40,60]$} & $\begin{array}{l}\text { Benthic } \\
\text { invertebrates }\end{array}$ & & fibres & $\begin{array}{l}\text { PP, PES, } \\
\text { ACR, } \\
\text { MACR, VI, } \\
\text { NF }\end{array}$ & $\begin{array}{l}\text { Taylor et al., } \\
2016\end{array}$ \\
\hline $\begin{array}{l}\text { Coastal waters of } \\
\text { Kochi, Southeastern } \\
\text { Arabian Sea, India }\end{array}$ & 9.9 & 76.6 & $\begin{array}{l}\text { Benthic } \\
\text { invertebrates }\end{array}$ & & $\begin{array}{l}\text { particles, } \\
\text { fibres }\end{array}$ & PP & $\begin{array}{l}\text { Naidu et al., } \\
2018\end{array}$ \\
\hline $\begin{array}{l}\text { Fishing harbour of } \\
\text { Chennai, } \\
\text { Southeastern Arabian } \\
\text { Sea, India }\end{array}$ & 13.2 & 80.3 & Bivalves & $\begin{array}{l}{[0.005,} \\
0.03]\end{array}$ & $\begin{array}{l}\text { particles, } \\
\text { fibres, } \\
\text { colorants }\end{array}$ & $\begin{array}{l}\text { PP and } \\
\text { colorants** }\end{array}$ & Naidu, , 2019 \\
\hline $\begin{array}{l}\text { Chennai coast, } \\
\text { southeast coast of } \\
\text { India }\end{array}$ & 13 & 81.3 & Beaches & {$[2,5]$} & $\begin{array}{l}\text { ovoid, } \\
\text { spheroids, } \\
\text { disks, } \\
\text { cylindrical } \\
\text { rods }\end{array}$ & PE, PP & $\begin{array}{l}\text { Veerasingam } \\
\text { et al., 2016a }\end{array}$ \\
\hline $\begin{array}{l}\text { Beaches of Goa, } \\
\text { India }\end{array}$ & $\begin{array}{l}{[15.0} \\
15.75]\end{array}$ & $\begin{array}{l}{[73.75,} \\
74.25]\end{array}$ & Beaches & {$[1,5]$} & $\begin{array}{l}\text { cylindrical, } \\
\text { spherical, } \\
\text { oval }\end{array}$ & PE, PP & $\begin{array}{l}\text { Veerasingam } \\
\text { et al., 2016b }\end{array}$ \\
\hline $\begin{array}{l}\text { Vembanad Lake, } \\
\text { Kerala, India }\end{array}$ & {$[9.5,10.2]$} & {$[76.2,76.4]$} & $\begin{array}{l}\text { Lake and } \\
\text { estuarine } \\
\text { sediment }\end{array}$ & $<5$ & $\begin{array}{l}\text { fibre, pellet, } \\
\text { fragment, } \\
\text { foam, film }\end{array}$ & $\begin{array}{l}\text { HDPE, } \\
\text { LDPE, PP, } \\
\text { PS }\end{array}$ & $\begin{array}{l}\text { Sruthy and } \\
\text { Ramasamy, } \\
2016\end{array}$ \\
\hline $\begin{array}{l}\text { Coastal areas, Tamil } \\
\text { Nadu, India }\end{array}$ & {$[8.1,13.1]$} & $\begin{array}{l}{[77.95,} \\
80.5]\end{array}$ & Beaches & {$[0.5,3]$} & $\begin{array}{l}\text { fibre, } \\
\text { fragment, } \\
\text { foam, }\end{array}$ & $\begin{array}{l}\text { PE, PP, PS, } \\
\text { NY, PES }\end{array}$ & $\begin{array}{l}\text { Sathish et al., } \\
2019\end{array}$ \\
\hline $\begin{array}{l}\text { Tamil Nadu coast, } \\
\text { India }\end{array}$ & {$[8,13]$} & {$[78,80]$} & Beaches & {$[0.3,9]$} & $\begin{array}{l}\text { fragments, } \\
\text { foam, } \\
\text { pellets, } \\
\text { film, fibres }\end{array}$ & $\begin{array}{l}\text { PE, PP, PS, } \\
\text { NY }\end{array}$ & $\begin{array}{l}\text { Karthik et al., } \\
2018\end{array}$ \\
\hline $\begin{array}{l}\text { Tamil Nadu coast, } \\
\text { India }\end{array}$ & {$[8,13]$} & {$[78,80]$} & Fish fauna & $<0.5$ & $\begin{array}{l}\text { fragments, } \\
\text { fibres }\end{array}$ & PE, PP, & $\begin{array}{l}\text { Karthik et al., } \\
2018\end{array}$ \\
\hline $\begin{array}{l}\text { Super markets in } \\
\text { Mumbai, India }\end{array}$ & & & $\begin{array}{l}\text { Commercial } \\
\text { salts }\end{array}$ & $\begin{array}{l}{[<0.021,} \\
7]\end{array}$ & $\begin{array}{l}\text { fragments, } \\
\text { fibres }\end{array}$ & $\begin{array}{l}\text { PES, PET, } \\
\text { PA, PE, PS }\end{array}$ & $\begin{array}{l}\text { Seth and } \\
\text { Shriwastav, } \\
2018\end{array}$ \\
\hline $\begin{array}{l}\text { Alang-Sosiya ship- } \\
\text { breaking yard, } \\
\text { Gujarath, India }\end{array}$ & 22 & 72 & $\begin{array}{l}\text { Intertidal } \\
\text { sediment }\end{array}$ & {$[0.0016,5]$} & $\begin{array}{l}\text { fragments, } \\
\text { fibres, films }\end{array}$ & $\begin{array}{l}\text { PU, NY, } \\
\text { PES, PS }\end{array}$ & $\begin{array}{l}\text { Reddy et al., } \\
2006\end{array}$ \\
\hline Mumbai, India & 18.9 & 72.9 & Beaches & {$[<5,>100]$} & $\begin{array}{l}\text { fragments, } \\
\text { pellets }\end{array}$ & & $\begin{array}{l}\text { Jayasiri et al., } \\
2013\end{array}$ \\
\hline $\begin{array}{l}\text { Southwest coast of } \\
\text { India }\end{array}$ & {$[8.3,12.8]$} & {$[74.9,77.4]$} & $\begin{array}{l}\text { Surface waters, } \\
\text { sediment, fish } \\
\text { fauna }\end{array}$ & {$[0.3,5]$} & $\begin{array}{l}\text { pellets, } \\
\text { film, } \\
\text { fragments, }\end{array}$ & $\begin{array}{l}\text { PE, CE, } \\
\text { PES, PP, } \\
\text { RY }\end{array}$ & $\begin{array}{l}\text { Robin et al., } \\
2020\end{array}$ \\
\hline
\end{tabular}




\begin{tabular}{|c|c|c|c|c|c|c|c|}
\hline \multirow{2}{*}{ Location } & \multirow{2}{*}{$\begin{array}{c}\text { Latitud } \\
\text { e } \\
{\left[{ }^{\circ} \mathrm{N}\right]}\end{array}$} & \multirow{2}{*}{$\begin{array}{c}\text { Longitud } \\
\mathbf{e} \\
{\left[{ }^{\circ} \mathbf{E}\right]}\end{array}$} & \multirow{2}{*}{$\begin{array}{c}\text { Observation } \\
\text { s }\end{array}$} & \multicolumn{3}{|c|}{ Categories* } & \multirow{2}{*}{ Reference } \\
\hline & & & & $\begin{array}{l}\text { Size } \\
{[\mathrm{mm}]}\end{array}$ & $\begin{array}{l}\text { Shape/ty } \\
\text { pe }\end{array}$ & Polymers & \\
\hline & & & & & $\begin{array}{l}\text { fibres/line, } \\
\text { foam }\end{array}$ & & \\
\hline $\begin{array}{l}\text { Biawak Island, north } \\
\text { coast of Indramayu, } \\
\text { Indonesia }\end{array}$ & -5.9 & 108.4 & $\begin{array}{l}\text { Below water } \\
\text { surface, fish } \\
\text { fauna }\end{array}$ & {$[1,5]$} & $\begin{array}{l}\text { fragments, } \\
\text { fibres }\end{array}$ & & $\begin{array}{l}\text { Ismail et al., } \\
2018\end{array}$ \\
\hline $\begin{array}{l}\text { Along Cilacap's } \\
\text { coast, Indonesia }\end{array}$ & $\begin{array}{c}{[-18.4,} \\
-7,7]\end{array}$ & 109.1 & $\begin{array}{l}\text { Surface waters, } \\
\text { beaches }\end{array}$ & {$[2.5,5]$} & & $\begin{array}{l}\text { PP, LDPE, } \\
\text { HDPE, } \\
\text { PVC, PET, } \\
\text { PS, PC }\end{array}$ & $\begin{array}{l}\text { Syakti et al., } \\
2017\end{array}$ \\
\hline $\begin{array}{l}\text { Coastal sediments of } \\
\text { Khark Island, Iran }\end{array}$ & 29.35 & 50.5 & Coastal sediment & {$[0.1,5]$} & $\begin{array}{l}\text { fragments, } \\
\text { fibres }\end{array}$ & & $\begin{array}{l}\text { Akhbarizadeh } \\
\text { et al., } 2016\end{array}$ \\
\hline $\begin{array}{l}\text { Chabahar Bay, Gulf } \\
\text { of Oman ((Makran } \\
\text { Coasts), Iran }\end{array}$ & 25.3 & 60.4 & Surface waters & {$[0.1,5]$} & $\begin{array}{l}\text { fragment, } \\
\text { pellets, } \\
\text { fibres paint } \\
\text { flakes }\end{array}$ & $\begin{array}{l}\text { PE, PP, } \\
\text { PES }\end{array}$ & $\begin{array}{l}\text { Aliabad et al., } \\
2019\end{array}$ \\
\hline Asaluyeh city, Iran & 27.53 & 52.6 & $\begin{array}{l}\text { Air and street } \\
\text { dust }\end{array}$ & {$[<0.1,>1]$} & $\begin{array}{l}\text { fragments, } \\
\text { fibres, } \\
\text { films, } \\
\text { spheroids }\end{array}$ & & $\begin{array}{l}\text { Abbasi et al., } \\
2019\end{array}$ \\
\hline $\begin{array}{l}\text { Iranian coast of the } \\
\text { Persian Gulf, Iran }\end{array}$ & 26.97 & 55.0 & Molluscans & {$[0.01,5]$} & $\begin{array}{l}\text { fragments, } \\
\text { fibres, } \\
\text { films, } \\
\text { pellets }\end{array}$ & $\begin{array}{l}\text { PE, PET, } \\
\text { NY }\end{array}$ & $\begin{array}{l}\text { Naji et al., } \\
2018\end{array}$ \\
\hline Kenyan coastline & 1.7 & $39.2^{\circ} \mathrm{E}$ & $\begin{array}{l}\text { Surface waters, } \\
\text { zooplankton }\end{array}$ & {$[0.01,2.4]$} & $\begin{array}{l}\text { fragments, } \\
\text { fibres, } \\
\text { pellets, } \\
\text { film, foam }\end{array}$ & $\begin{array}{l}\text { PP, LDPE; } \\
\text { LDPE }\end{array}$ & $\begin{array}{l}\text { Kosore et al., } \\
2018\end{array}$ \\
\hline $\begin{array}{l}\text { Kuala Nerus and } \\
\text { Kuantan, Malaysia }\end{array}$ & & & Surface waters & $<5$ & $\begin{array}{l}\text { filaments, } \\
\text { fragments, } \\
\text { irregular }\end{array}$ & $\begin{array}{l}\text { PES, PE, } \\
\text { PA, PVC, } \\
\text { PP, PS }\end{array}$ & $\begin{array}{l}\text { Khalik et al., } \\
2018\end{array}$ \\
\hline Skudai and Tebrau & 1.5 & $\begin{array}{l}103^{\circ} 24^{\prime} \\
85^{\prime \prime} \mathrm{E}\end{array}$ & River sediment & {$[0.1,5]$} & $\begin{array}{l}\text { fibres/line, } \\
\text { fragments, } \\
\text { film, foam, } \\
\text { beads/pellet } \\
\text { s }\end{array}$ & & $\begin{array}{l}\text { Sarijan et al., } \\
2018\end{array}$ \\
\hline $\begin{array}{l}\text { Maldivian } \\
\text { archipelago }\end{array}$ & 3.1 & 72.97 & $\begin{array}{l}\text { Surface waters, } \\
\text { corals }\end{array}$ & $<5$ & $\begin{array}{l}\text { fragments, } \\
\text { films, } \\
\text { filaments, } \\
\text { foam }\end{array}$ & $\begin{array}{l}\text { PAHs, PE, } \\
\text { PP, PA, PS, } \\
\text { PU }\end{array}$ & $\begin{array}{l}\text { Saliu et al., } \\
2019\end{array}$ \\
\hline $\begin{array}{l}\text { Maldivian } \\
\text { archipelago }\end{array}$ & 3.1 & 72.97 & corals & & & $\begin{array}{l}\text { MEP, } \\
\text { DEP,DBP, } \\
\text { MEPH,BBz } \\
\mathrm{P}^{*}\end{array}$ & $\begin{array}{l}\text { Saliu et al., } \\
2019\end{array}$ \\
\hline $\begin{array}{l}\text { Faafu Atoll, } \\
\text { Maldives }\end{array}$ & 3.1 & 72.97 & Surface waters & {$[0.05,25]$} & $\begin{array}{l}\text { fragments, } \\
\text { foils, } \\
\text { pellets, } \\
\text { fibres, foam }\end{array}$ & $\begin{array}{l}\text { PE, PP, PS, } \\
\text { PET, PU, } \\
\text { PVC }\end{array}$ & $\begin{array}{l}\text { Saliu et al., } \\
2018\end{array}$ \\
\hline
\end{tabular}




\begin{tabular}{|c|c|c|c|c|c|c|c|}
\hline \multirow{2}{*}{ Location } & \multirow{2}{*}{$\begin{array}{c}\text { Latitud } \\
\text { e } \\
{\left[{ }^{\circ} \mathrm{N}\right]}\end{array}$} & \multirow{2}{*}{$\begin{array}{c}\text { Longitud } \\
\mathbf{e} \\
{\left[{ }^{\circ} \mathbf{E}\right]}\end{array}$} & \multirow{2}{*}{$\begin{array}{c}\text { Observation } \\
\mathbf{s}\end{array}$} & \multicolumn{3}{|c|}{ Categories* } & \multirow{2}{*}{ Reference } \\
\hline & & & & $\begin{array}{l}\text { Size } \\
{[\mathrm{mm}]}\end{array}$ & $\begin{array}{l}\text { Shape/ty } \\
\text { pe }\end{array}$ & Polymers & \\
\hline $\begin{array}{l}\text { Faafu Atoll, } \\
\text { Maldives }\end{array}$ & 3.1 & 72.97 & Sediments & {$[0.05,25]$} & $\begin{array}{l}\text { fragments, } \\
\text { foils, } \\
\text { pellets, } \\
\text { fibres, foam }\end{array}$ & $\begin{array}{l}\text { PE, PP, } \\
\text { PET, PS, } \\
\text { PA, PAN, } \\
\text { PU, PVC, } \\
\text { PVDF }\end{array}$ & $\begin{array}{l}\text { Saliu et al., } \\
2018\end{array}$ \\
\hline Doha Bay, Qatar & 25.5 & 50.1 & Surface waters & {$[<0.5,5]$} & $\begin{array}{l}\text { fibre, film, } \\
\text { fragment }\end{array}$ & $\begin{array}{l}\text { LDPE, } \\
\text { LDPP }\end{array}$ & $\begin{array}{l}\text { Abayomi etal., } \\
2017\end{array}$ \\
\hline Coastline of Qatar & 25.5 & 50.1 & Beaches & {$[<0.5,5]$} & $\begin{array}{l}\text { fibre, film, } \\
\text { fragment }\end{array}$ & $\begin{array}{l}\text { LDPE, } \\
\text { LDPP }\end{array}$ & $\begin{array}{l}\text { Abayomi et al., } \\
2017\end{array}$ \\
\hline $\begin{array}{l}\text { Northeastern Qatar } \\
\text { EEZ }\end{array}$ & 25.3 & 52.4 & Surface waters & $\begin{array}{l}{[<0.125,} \\
15.98]\end{array}$ & $\begin{array}{l}\text { granules, } \\
\text { fibres }\end{array}$ & $\begin{array}{l}\text { PP, PE, } \\
\text { LDPE, PA, } \\
\text { ABS }\end{array}$ & $\begin{array}{l}\text { Castillo et al., } \\
2016\end{array}$ \\
\hline $\begin{array}{l}\text { Coast of Red Sea, } \\
\text { Saudi Arabia }\end{array}$ & {$[20,28]$} & {$[35,40]$} & Fish fauna & {$[1,3]$} & $\begin{array}{l}\text { fragments, } \\
\text { films, fibres }\end{array}$ & $\begin{array}{l}\text { PP, PE, PS, } \\
\text { PVC, PAN }\end{array}$ & $\begin{array}{l}\text { Baalkhuyur et } \\
\text { al., } 2019\end{array}$ \\
\hline $\begin{array}{l}\text { Alphonse Island, } \\
\text { Western Indian } \\
\text { Ocean, Seychelles }\end{array}$ & -7 & 52.7 & Beaches & & $\begin{array}{l}\text { fragments, } \\
\text { fishing nets, } \\
\text { glass bottles }\end{array}$ & $\begin{array}{l}\text { PET, PVC, } \\
\text { PP, HDPE, } \\
\text { PE, PS }\end{array}$ & $\begin{array}{l}\text { Duhec et al., } \\
2015\end{array}$ \\
\hline $\begin{array}{l}\text { Mangrove sediments, } \\
\text { northwest coast of } \\
\text { Singapore }\end{array}$ & 1.2 & & Sediments & {$[<0.02,5]$} & $\begin{array}{l}\text { fibres, } \\
\text { films, } \\
\text { granules }\end{array}$ & $\begin{array}{l}\text { PE, PP, } \\
\text { NY, PVC }\end{array}$ & $\begin{array}{l}\text { Nor and } \\
\text { Obbard, } 2014\end{array}$ \\
\hline $\begin{array}{l}\text { Southern coastline of } \\
\text { Sri Lanka }\end{array}$ & & & $\begin{array}{l}\text { Surface waters, } \\
\text { beaches }\end{array}$ & {$[1.5,4.5]$} & $\begin{array}{l}\text { pellets, } \\
\text { fragments, } \\
\text { films, } \\
\text { filaments, } \\
\text { foam }\end{array}$ & PE, PP, PS & $\begin{array}{l}\text { Koongolla et } \\
\text { al., } 2018\end{array}$ \\
\hline $\begin{array}{l}\text { Intertidal area of } \\
\text { eastern coastal } \\
\text { Thailand }\end{array}$ & 13 & 101 & $\begin{array}{l}\text { Sessile } \\
\text { invertebrates }\end{array}$ & $<0.1$ & $\begin{array}{l}\text { rod, } \\
\text { fragments, } \\
\text { fibres }\end{array}$ & $\begin{array}{l}\text { PS, PET, } \\
\text { PA }\end{array}$ & $\begin{array}{l}\text { Thusharia et } \\
\text { al., } 2017\end{array}$ \\
\hline $\begin{array}{l}\text { Transkei, South } \\
\text { Africa }\end{array}$ & -31.75 & 29.38 & Beaches & & & & $\begin{array}{l}\text { Madzena and } \\
\text { Lasiak } 1997\end{array}$ \\
\hline Prince Edward Island & -46.61 & 37.96 & Beaches & & & & Ryan, 1987 \\
\hline Marion Island & -46.84 & 37.85 & Beaches & & & & Ryan, 1987 \\
\hline Heard Island & -53.00 & 73.48 & Beaches & & & & $\begin{array}{l}\text { Slip and } \\
\text { Burton, } 1991\end{array}$ \\
\hline Macquarie Island & -54.62 & 158.80 & Beaches & & & & $\begin{array}{l}\text { Slip and } \\
\text { Burton, } 1991\end{array}$ \\
\hline $\begin{array}{l}\text { Jakarta Bay, } \\
\text { Indonesia }\end{array}$ & -5.86 & 106.85 & Beaches & & & & $\begin{array}{l}\text { Uneputty and } \\
\text { Evans } 1997\end{array}$ \\
\hline Negombo, Sri Lanka & 7.16 & 79.82 & Beaches & & & & Barnes, 2004 \\
\hline Ari Atoll, Maldives & 3.88 & 72.83 & Beaches & & & & Barnes, 2004 \\
\hline $\begin{array}{l}\text { Pemba Island, } \\
\text { Tanzania }\end{array}$ & -5.30 & 39.85 & Beaches & & & & Barnes, 2004 \\
\hline Diego Garcia & -7.34 & 72.51 & Beaches & & & & Barnes, 2004 \\
\hline Christmas Island & -10.54 & 105.59 & Beaches & & & & Barnes, 2004 \\
\hline $\begin{array}{l}\text { Cocos (Keeling) } \\
\text { Islands }\end{array}$ & -12.08 & 96.88 & Beaches & & & & Barnes,(2004 \\
\hline
\end{tabular}




\begin{tabular}{|c|c|c|c|c|c|c|c|}
\hline \multirow{2}{*}{ Location } & \multirow{2}{*}{$\begin{array}{c}\text { Latitud } \\
\mathbf{e} \\
{\left[{ }^{\circ} \mathrm{N}\right]}\end{array}$} & \multirow{2}{*}{$\begin{array}{c}\text { Longitud } \\
\mathbf{e} \\
{\left[{ }^{\circ} \mathbf{E}\right]}\end{array}$} & \multirow{2}{*}{$\begin{array}{c}\text { Observation } \\
\text { s }\end{array}$} & \multicolumn{3}{|c|}{ Categories* } & \multirow{2}{*}{ Reference } \\
\hline & & & & $\begin{array}{l}\text { Size } \\
{[\mathrm{mm}]}\end{array}$ & $\begin{array}{l}\text { Shape/ty } \\
\text { pe }\end{array}$ & Polymers & \\
\hline $\begin{array}{l}\text { Quirimba Island, } \\
\text { Mozambique }\end{array}$ & -12.44 & 40.62 & Beaches & & & & Barnes, 2004 \\
\hline Rodrigues Island & -19.76 & 63.46 & Beaches & & & & Barnes, 2004 \\
\hline $\begin{array}{l}\text { Nosy Ve, } \\
\text { Madagascar }\end{array}$ & -23.64 & 43.50 & Beaches & & & & Barnes, 2004 \\
\hline $\begin{array}{l}\text { Inhaca Island, } \\
\text { Mozambique }\end{array}$ & -26.02 & 33.00 & Beaches & & & & Barnes,(2004 \\
\hline $\begin{array}{l}\text { South-east coast } \\
\text { South Africa }\end{array}$ & -34.00 & 24.00 & Beaches & & & & $\begin{array}{l}\text { Nel and } \\
\text { Froneman } \\
2015\end{array}$ \\
\hline $\begin{array}{l}\text { St. Brandon's Rock, } \\
\text { Mauritius }\end{array}$ & -16.38 & 59.45 & Beaches & & & & $\begin{array}{l}\text { Bouwman et } \\
\text { al., } 2016\end{array}$ \\
\hline Chennai, India & 13.05 & 80.28 & Beaches & & & & $\begin{array}{l}\text { Arun Kumar et } \\
\text { al., } 2016\end{array}$ \\
\hline $\begin{array}{l}\text { Vavvaru Island, } \\
\text { Maldives }\end{array}$ & 5.42 & 73.35 & Beaches & & & & $\begin{array}{l}\text { Imhof et al., } \\
2017\end{array}$ \\
\hline $\begin{array}{l}\text { Cocos (Keeling) } \\
\text { Islands }\end{array}$ & -12.08 & 96.88 & Beaches & & & & $\begin{array}{l}\text { Lavers et al., } \\
2019\end{array}$ \\
\hline
\end{tabular}

*denotes phthalate esters (BBzP), ** colorants (dyes or pigments). acrylonitrile butadiene styrene (ABS); modified acrylic (MACR); polycarbonate (PC); acetate (ACT); acrylic (ACR); acrylonitrile butadiene styrene (ABS); benzyl butyl phthalate (BBzP); bis(2ethylhexyl) phthalate (DEHP); di-butyl phthalate (DBP); di-ethyl phthalate (DEP); di-methyl phthalate (MEP); high density polyethylene (HDPE); low density polyethylene (LDPE); low density polypropylene (LDPP); mono (2-ethylhexyl) phthalate 1045 (MEPH); natural fibres (NF); nylon (NY); phthalic acid esters (PAHs); polyacrylonitrile (PAN); polyamide (PA); polyester (PES); polyethylene (PE); polyethylene terephthalate (PET); polypropylene (PP); polystyrene (PS); polyurethane (PU); polyvinylchloride (PVC); rayon (RY); viscose (VI). 